\title{
DOES CSR ENCOURAGE CUSTOMER LOYALTY: A CASE STUDY - LIBYAN TELECOM SECTOR?
}

\author{
Elhadi Eltweri ${ }^{*}$, Ahmed Eltweri ${ }^{* *}$ \\ * Liverpool Law School, the UK \\ ** Corresponding author, Liverpool Business School, the UK
}

Contact details: Liverpool Business School, Redmonds Building, Brownlow Hill, Liverpool, Merseyside, L3 5UG, the UK

\begin{abstract}
OPEN ACCESS
How to cite this paper: Eltweri, E., \& Eltweri, A. (2019). Does CSR encourage customer loyalty: A case study - Libyan telecom sector? Journal of Governance \& Regulation, 8(4), 64-81.

https://doi.org/10.22495/jgrv8i4art6

Copyright $(2019$ The Authors

This work is licensed under a Creative Commons Attribution 4.0 International License (CC BY 4.0).

https://creativecommons.org/licenses/by/ $4.0 /$

ISSN Print: 2220-9352

ISSN Online: 2306-6784

Received: 26.11 .2019

Accepted: 24.12 .2019

JEL Classification: L510, L530, L880, L960, M480

DOI: $10.22495 /$ jgrv8i4art6
\end{abstract}

\begin{abstract}
The study aims to the determination of the degree of customer awareness in relation to activities for customer social responsibility that should be undertaken by a company that is socially responsible, as well as to establish the influence that CSR has upon the loyalty of customers in the Libyan telecom sector. Given that, there is a great variety of developed countries that have welldeveloped telecom sectors which are closely monitored; however, the literature in developing countries that address the impact of CSR on customer loyalty is very limited. Therefore, the examination of the sector customers is of worth so that the meeting of needs for Libyan telecom sector customers can be assured. The survey was completed by 154 participants in total, and there was a recording of the web survey and analysis of the findings. Variables utilised for measurement of the influence of CSR upon the loyalty of customers were taken from the framework of theory with the inclusion of an economic CSR component, the legal CSR component, the philanthropic and ethical components of CSR and the loyalty of customers. The web-survey findings showed that customers had a great awareness of the activities of CSR that ought to be engaged in by responsible companies. In addition, the results showed that CSR did have an impact upon loyalty within the Libyan telecom sector and that customers had a willingness to buy from the firm because of the engagement of them in CSR activities.
\end{abstract}

Keywords: Corporate Social Responsibility, Corporate Governance, Emerging Economies, Customer Loyalties, Trust and Satisfaction of Consumer

Authors' individual contribution: Literature Review - E.E. and A.E.; Methodology - E.E.; Data Analysis - E.E. and A.E.; Writing - Original Draft - E.E.; Writing - Review \& Editing - E.E. and A.E.

\section{INTRODUCTION}

In recent decades, with their increased interest in the scrutiny of social and environmental matters and issues for systems of finance across the world, there has been growing interest in corporate social responsibility (CSR). Nowadays, therefore, lots of companies see CSR as part of a strategy rather than just a supportive program. Across the world, calls have been made that business organisations ought to give something back to the society within which their operations are located. Such calls are based on a belief that business corporation activities have been impacting negatively upon people due to pollution, industrial waste, products of poor quality and the neglect of employee rights, welfare and safety (Akinpelu, Ogunbi, Olaniran, \& Ogunseye, 2013). The concern over those critical issues has been growing and, whilst there can be a variety of definitions for CSR, it is an aim that is fundamental to them all to ensure that business is conducted by companies in ways that are more ethical with due account for environmental, economic and social impacts and human rights.

CSR can involve a variety of activities including projects for environmental protection and sustainability, relationship development with employees and customers, investment in socially responsible ways and partnership work with local communities. In addition, certain businesses can 
have the primary purpose of fulfilment of social and/or environmental goals, as opposed to a financially oriented business that attempts to minimise the negative impacts that operations may have upon society and/or the environment. Throughout human history, there has been an evolution in the perceived value of collective or individualistic social responsibility. Nowadays, major institutions across the world have a realisation that CSR is a key aspect to company operations since there are not only positive impacts for the general public, there can be positive impacts upon members of staff (Masruki, Zakaria, \& Ibrahim, 2012). CSR promoters have argued that there has to be an integration of environmental, economic and social concerns within the business strategies of institutions, in ways that go beyond simple compliance with greater investment in human, environmental and social capital and suitable management tools and activities (Enahoro, Akinyomi, \& Olutoye, 2013).

As a concept, CSR has a lot of attention across the world and now has a great deal of significance within the global economy (Enahoro et al., 2013). Whilst CSR is a relatively new phenomenon, many observers are in agreement that its prominence and growth has been spurred on by processes of globalisation (Rouf, 2011). As Wibowo (2012) noted, CSR is but one of the programs for sustainability that can be undertaken by companies. CSR can be described as the company commitment to be held accountable for its operations and activities to a variety of stakeholders (Fasanya \& Onakoya, 2013).

The structure of this paper is as follows: the literature review presented in Section 2, while the implemented methodology to accomplish the outcome in Section 3. Section 4 presents the findings of the survey along with the discussion and Section 5 concludes the paper.

\section{LITERATURE REVIEW}

\subsection{Corporate social responsibility (CSR)}

There has been increased interest in CSR in recent decades as more and more attention is paid to environmental and social matters and the impacts of global financial systems. Nowadays, lots of companies see CSR as integral to strategic management and not solely a matter for supportive programmes. Across the world, calls have been made for business organisations to take a more responsible approach and to give something back to the societies in which operations take place. Business corporation activities have begun to be viewed more in the light of all their negative impacts upon individuals and the larger society because of the manufacture of products of poor quality, the production of waste, industrial pollution and the neglect of employee welfare and rights and matters of health and safety (Akinpelu et al., 2013). With the growth in the rate of occurrence of these negative impacts, there has been an increase in concern being articulated over these issues. There are a variety of definitions for CSR; it is clear, however, that a fundamental aim is ensuring firms conduct business in ways that are more ethical with proper account taken of environmental, economic and social impacts and issues for human rights. Various activities may be included within CSR such as relationship development with employees and customers, projects for environmental protection and sustainability and partnership working with local communities. Certain businesses can, of course, have as their primary purpose the fulfilment of social and/or environmental goals, rather than attempting to reduce negative impacts upon society and/or the environment whilst maintaining, primarily financial goals. Nowadays, CSR is seen by employers as a way of increasing competitive advantage, building trust amongst both customers and employees and, simultaneously serving to protect and raise brand awareness. They have been moves towards giving firms encouragement to be more greatly aware of the impacts upon society (including firm stakeholders) and the environment due to their organisational activities/operations.

Throughout the course of human history, social responsibility, either for the individual or the collective, has been evolving in value. Nowadays, across the world, major institutions have begun to realise the CSR is a key element for company operations; it is seen as having a positive impact upon society/general public whilst, in turn, having a positive effect upon members of staff (Masruki et al., 2012). Those who promote CSR have argued that social, economic and environmental concerns ought to be integrated into business strategies in ways that go beyond simple compliance with greater investment in human, environmental and social capital and appropriate management activities and tools (Enahoro et al., 2013). As a concept, CSR has received a lot of attention across the world and is now seen as a new and important aspect of the global economy (Enahoro et al., 2013). For companies, it is, perhaps, a new phenomenon to incorporate social responsibility concepts within operations, however, there is now agreement amongst many observers that processes of globalisation have spurred on the prominence and growth of CSR (Rouf, 2011). It was outlined by Wibowo (2012) that CSR is one of a number of programmes for sustainability that a company can undertake. CSR can be described as a company's commitment to have accountability for all its operations and activities to various stakeholders (Fasanya \& Onakoya, 2013). There are, however, many different CSR definitions as well as a variety of ways in which it can be implemented. There can be huge variations, in reality, for how the concept of CSR is understood and put into practice from one country to another. Moreover, a broad conceptualisation of CSR may incorporate a variety of aspects to life; for example, it may touch upon human rights, health, safety and working conditions, corporate governance, environmental impacts and economic development.

Whatever the definition adopted for CSR, its purpose can, in general, be seen as a driving force behind achieving sustainable change. Even though significant efforts have been put into CSR by some firms through a variety of unique initiatives, it is difficult for any organisation to remain a leading company with regard to every aspect of CSR. Using the definition of the Industrial Development Organisation of the United Nations (UNIDO, 2018), CSR may be seen as a management concept whereby social and environmental concerns are integrated within business operations of companies and their interactions with stakeholders. 
Generally, it is understood that CSR is a way for companies to achieve an approach that is triplebottom line' in that there is a balancing of environmental, social and economic imperatives whilst, at the same time, addressing the expectations of shareholders and stakeholders. With good implementation of CSR, the concept can offer a firm a way of achieving competitive advantage by way of increased sales and profits, enhanced access to the market, improved productivity and quality, savings on costs of operations, efficiency in human resource terms, enhanced customer loyalty, better decisionmaking, enhanced image and reputation of brand(s) and improved risk management processes.

A broad definition of CSR is for it to be seen as 'a commitment to improve [societal] well-being through discretionary business practices and contributions of corporate resources' (Kotler \& Lee, 2008). Within the context of the current global market place, with its agenda of more socially conscious operations for corporations, CSR is now held in high regard. There is an ever-increasing devotion to CSR within major companies with considerable resources being put forward into various social initiatives ranging from programmes of outreach to the community to projects of environmental protection to changes to business practice to ensure they have a greater social responsibility in the first place. General Electric, for example, has invested heavily in its Healthymagination initiative, leading to billions of dollars being put towards healthcare technologies to reduce medical errors and improve patient lives $(\mathrm{Du}$, Bhattacharya, \& Sen, 2010).

\subsubsection{Key challenges for communicating CSR}

Unlike the information in relation to the ability of corporations, such as the superiority of products or new innovations, information related to CSR for a firm relates to aspects to business identity that are not solely fundamental and enduring but also are distinctive. Such distinctiveness is due to their basis is in disparate and idiosyncratic properties such as sponsorship of social causes, policy related to egalitarian employment and particular environmental initiatives. The communication of CSR, then, can be an affair that needs to be handled with a great deal of sensitivity and a key challenge for communication is minimising scepticism amongst shareholders and stakeholders and conveyance of motives intrinsic to firm activities related to CSR. The implication of the characteristics of information related to CSR is that it is essential for the attributes of stakeholders to be identified and their relationship to the underlying motives of activities related to CSR. In all likeliness, stakeholders may refrain from a positive inference with respect to firm identity if it is suspected that motives are ulterior and self-serving (Fein \& Hilton, 1994).

By way of utilisation of an open-ended survey that unearthed the range of motives that consumers attributed to CSR activities, Ellen, Webb, and Mohr (2006) found that the majority of respondents in their study gave mixed attributions; interestingly, there were mixed attributions for CSR with respondents reactions having, in reality, greater positivity than if there were purely intrinsic or extrinsic attributions. Also, finding from the work of
Ellen et al. (2006) were consistent as it is often the case that stakeholders have tolerance for motives that are extrinsic if, in addition, there is the attribution of CSR initiatives to intrinsic motives. The work of Sen, Bhattacharya, and Korschun (2006) has relevance here too. Growing tolerance of extrinsic motives indicates that with greater learning amongst consumers with respect to CSR and company motivations, there is more willingness to adopt perspectives that accommodate 'win-win' scenarios; that way, CSR initiatives are seen as potentially serving the needs of both the business bottom-line and wider society. Foreh and Grier (2003) argued that there is not a tendency amongst stakeholders to respond negatively with regard to extrinsic CSR motives; there is, instead, a tendency for responses to be negative to any type of strategy for marketing that seems to be manipulative or deceptive. The work of Foreh and Grier (2003) showed that, by way of acknowledgement of both intrinsic and extrinsic motives within CSR-related communication, a firm can generate a sense of goodwill, enhance the perception of the credibility of the message, and inhibit stakeholder scepticism. In summary, it can be said that a key challenge for designing effective strategies for communication for CSR is the reduction of stakeholder scepticism and the conveying of the organisational motives with regard to CSR activities in ways that they are perceived in a light that is favourable.

\subsection{Customer loyalty}

For companies, a primary goal is to have loyal customers, particularly when in tough economic circumstances such as when a global recession hits (Pérez, del Mar García de los Salmones, \& Rodríguez del Bosque, 2013). Within such a context, loyal customers become a key resource for a company with profits affected directly by the degree of loyalty shown (Edvardsson, Johnson, Gustafsson, \& Strandvik, 2000). It has been shown by scholars that the construction of a corporate image that is appealing helps companies to enhance the degree of loyalty amongst customers through their behaviour with regard to repurchasing and the making of recommendations (Chaudhuri \& Holbrook, 2001). The image of a corporation is a construct with multidimensionality with it referring to stakeholder group perceptions (Pérez \& Rodríguez del Bosque, 2015a). Often, scholars may a division of dimensions of the corporate image between the image of CSR and image in relation to corporate ability (CA) (Brown \& Dacin, 1997). CA image relates to perceptions of the skill and expertise of a company in the production and delivery of the service and product offerings. The image in relation to CSR, on the other hand, is in reference to the knowledge and perception of the activities and status of a company in relation to its obligations to stakeholders and society (He \& Li, 2011).

There are increasing levels of pressure upon companies to enhance socially-oriented initiatives since CSR has become an ethical and moral standard for present-day society and since it comes with implications for corporate performance and customer behaviour (He \& Li, 2011). Brand loyalty was defined by Oliver (1999), however, as "a deeply held commitment to re-buy or re-patronize a preferred product/service consistently in the future, 
thereby causing repetitive same-brand or same brand-set purchasing, despite situational influences and marketing efforts having the potential to cause switching behavior." Also, it was suggested by Chaudhuri and Holbrook (2001) that purchase or behavioural loyalty was made up of repeated purchases of a brand; attitudinal loyalty, on the other hand, includes some aspects of commitment that is dispositional in relation to some value that is unique that has been associated to the brand in question. Customer loyalty, then, is considered here as a bi-dimensional property that included both behavioural intention to re-purchase and attitudinal commitment. Based upon previous research, the loyalty of customers was defined in terms of the favourable attitude of customers to a brand that resulted in the behaviour of repeat purchasing (Anderson \& Srinivasan, 2003; Keller, 1993).

\subsubsection{The influence of CSR on the loyalty of consumers}

Since customer loyalty is an integral part of success for business within a competitive market, various studies have undertaken examinations of various factors that can have a bearing on the motivation of consumers to keep being loyal to the services and products of companies (Kotler \& Armstrong, 2010; Orel \& Kara, 2014). There has not, however, been a great deal of emphasis placed upon the effects of CSR upon attracting and increasing numbers of loyal consumers (Liu, Guo, \& Lee, 2011). Typically, CSR consists of ethical, philanthropic and legal responsibilities representative of the concern of a company for the society within it sits (Stanaland, Lwin, \& Murphy, 2011). In addition, the selfregulatory mechanisms serve in monitoring whether or not a company is in compliance with such responsibilities. Application of the concept is a potential way of increasing the loyalty of consumers and could be determinants that influence CSR outcomes with respect to loyalty within the telecom sector. Previous research has had a primary focus on the investigation of the CSR role in the improvement of financial performance and evaluations of products through a focus upon corporate perspectives upon CSR activities (Lee, Park, Rapert, \& Newman, 2012). There is, however, increasing recognition of the important role played by CSR in the shaping of the perceptions of consumers and company valuations (Christopher \& Luke, 2013). Awareness of CSR amongst consumers does remain low, however, and companies often have results that are unsatisfactory even though large amounts of resources are now dedicated to activities related to CSR (Lee et al., 2012). Researchers and companies, therefore, ought to explore factors associated with the perceptions that consumers have of CSR and undertake investigations into the role those factors play in the shaping of the loyalty of consumers. The effect that consumer perceptions of activities related to CSR have upon reactions of loyalty shows the potential for benefits in terms of behavioural outcomes such as loyalty (Barone, Miyazaki, \& Taylor, 2000; Klein \& Dawar, 2004; Lichtenstein, Drumwright, \& Braig, 2004). In addition, CSR can have positive effects upon evaluations of a product or a company in general by consumers, and positively affect the willingness of a consumer to undertake a purchase of the products in question (Sen \& Bhattacharya, 2001).
Consumer loyalty can also be directly influenced by CSR (Sureshchandar, Rajendran, \& Anantharaman, 2002). More precisely, there can be positive impacts upon the loyalty that consumers have to a company if it is perceived as engaging in behaviour that is socially responsible (Crespo \& Rodríguez del Bosque, 2005). Indeed, associations with social responsibility can be helpful in strengthening a sense of trust and the union that a consumer feels to a company (Maignan, Ferrell, \& Hult, 1999). So, therefore, perceptions of behaviour that is socially responsible may serve to strengthen the commitment shown towards a particular brand. Large consumer numbers do claim to have a greater willingness to purchase products from firms perceived to have involvement with social causes rather than those who do not (Ross, Patterson, \& Stutts, 1992). So, there are some people who are likely to value the efforts of companies in regard to programmes and donations, the conservation of energy, sponsorship of local events and such like, and such support can lead to a sense of stronger loyalty to a particular company (Maignan et al., 1999).

\subsubsection{Trust}

Trust can be considered as the degree of confidence in the reliability and integrity of a partner within an exchange. Pavlou and Fygenson (2006) conceptualised and defined trust as the degree of belief consumers have in companies with respect to whether actions/operations are ethical, responsible, favourable and legal. If a company is seen as being trustworthy with operations perceived as being done with ethical and social responsibility, then the consumer is more likely to be confident in the quality of product or service; trust and confidence in a form leads to consumers being more willing to repurchase products and reuse services (Gefen, Straub, \& Boudreau, 2000). Trust has been identified within academic literature as a prerequisite for the preservation and creation of long-term relationships between consumers and a company, particular within the context of the service sector (Morgan \& Hunt, 1994). Reichheld and Schefter (2000) observed that gaining loyalty from customers requires, first of all, the gaining of their trust. Furthermore, the trust of consumers has been defined in terms of a belief that there can be reliance upon the provision of products or services being done in such a way that long-term customer interests will be served (Crosby, Evans, \& Cowles, 1990). Trust is first of all needed to gain the loyalty of customers. Sirdeshmukh, Singh, and Sabol (2002) showed that trust can be seen as being composed of two main elements, namely benevolence trust and performance or credibility trust. The trust of consumers, however, can be affected by the sharing of values between consumers and the company (Morgan \& Hunt, 1994) as with consumer and company identification, CSR can have a positive impact upon trust (Kennedy, Ferrell, \& LeClair, 2001; Swaen \& Chumpitaz, 2008). With regard to initiatives for CSR, behaviour gives information about values and the character of a corporation, and such information can be helpful in enhancement of the general sense of trust felt toward an organisation (Aaker, 1996). As stated by Hosmer (1994), through the injection of responsible and ethical principles into the processes of strategic decision-making, a firm may enhance trust amongst 
customers and other stakeholders. A perception that a firm is responsible and ethical can stimulate relationships based on trust with a belief that all the actions of the exchange partner will have credibility beyond any legal or contractual constraints (Swaen \& Chumpitaz, 2008). Pivato, Misani, and Tencati (2008) supported such a view and proposed that trust creation is an immediate consequence of the social performance of a company or the most proximate or immediate outcome of activities for CSR (other less central outcomes being behaviours, attitudes and performance in financial terms). So, based upon these notions of trust, it is considered that CSR will have a positive impact on the trust of customers.

\subsubsection{Satisfaction}

In general, consumer satisfaction may be determined with respect to communication that is shared with the service provider and/or the quality of experience (Crosby et al., 1990). It is suggested within the academic literature that customers will have an inclination to re-purchase services or products if they are satisfied with the brands they have chosen and, finally, they may become loyal with a stronger sense of goodwill towards the brands. Research has indicated that the satisfaction of customers has a positive significant influence upon the retention of them, the usage of services and upon customer purchase share; as such, customer satisfaction can be seen as a primary antecedent of customer loyalty (Verhoef, 2003). For example, Lee, Huang, and Hsu (2007) argued that high levels of satisfaction create bonds, associated with feelings of fulfilment and pleasure, inducing a degree of commitment between consumers and firms. Likewise, there is a suggestion from the academic literature that associations of CSR may have an impact upon customer satisfaction (Alcañiz, Herrera, Manzano, \& Pérez, 2011; He \& Li, 2011). Associations of CSR, however, create a context around a company that is favourable that stimulates more of an outpouring of favourable judgments towards the experience of a service (Brown \& Dacin, 1997); as such, these customers would tend to have greater understanding with respect to failure of the delivery of services to improve satisfaction. Three reasons for what has been termed the effect of 'CSR activities-customer satisfaction' were articulated by Luo and Bhattacharya (2006). First of all, as was suggested by Maignan, Ferrell, and Ferrell (2005), customers of a company may be potential stakeholders with care for not only its economic performance but also its social performance and overall standing. So, there is more likeliness of a customer being satisfied when product or service providers develop initiatives for CSR and present themselves as having more sociallyoriented and responsible behaviour towards society in general (He \& Li, 2011). Secondly, a robust CSR record leads to an image that is favourable that enhances positively the evaluation that a consumer has of a firm and improves attitudes towards what they do (Sen \& Bhattacharya, 2001).

Furthermore, initiatives for CSR are key to corporate identity and may lead to customers identifying with a company and having improved levels of satisfaction with the offerings of a firm (Bhattacharya \& Sen, 2003). Thirdly, as Mithas, Krishnan, and Fornell (2005) empirically demonstrated, a key antecedent to the promotion of customer satisfaction is perceived value. Better perceived value is more likely to be derived by customers and, as a consequence, greater satisfaction gained, from products made by companies that are socially responsible (Luo \& Bhattacharya, 2006). In line with such thinking, it is argued within this paper that CSR has an impact on customer satisfaction.

\subsubsection{Service quality}

Quality of service is an issue currently stressed in a variety of areas and is a key to whether businesses can be sustainable. Over the long-term, the provision of high-quality services is vital to the survival of a business. As explained by Kang (2006), service quality is "the imaginary expected performance against real performance. The ability of a firm to maintain competitive advantage relies, in effect, upon the actuality of offering an exceptional service (Kyoon Yoo \& Ah Park, 2007). It was argued by Bediako (2017) that the offering of a product of quality may increase satisfaction in the perceptions of customers. Churchill and Surprenant (1982) considered that the quality of service relates to the gap lying between expectations and the actual level of satisfaction felt by a customer once a service is accepted. Based upon the service industry characteristics, service quality can be divided into three dimensions, i.e. equipment, material and personnel. Few previous studies have explored whether CSR has an impact on the quality of service of corporations. There is only the research conducted by Chiu (2009) that noted that when consumers have high levels of perception with regard to CSR, they have higher levels of perceptions of quality of service and higher levels of intentions to repurchase. Brammer and Millington (2005) also found that corporations that engage in events that are charitable can help in the enhancement of reputation and corporate image. It was discovered by Lichtenstein, Ridgway, and Netemeyer (1993) that the implementation of activities of CSR can bring corporations good results such as improved purchasing behaviour and improved views of consumers. Lastly, increasing service quality not only leads to the enhancement of corporate image but it also leads to enhancement in customer loyalty and satisfaction. So, based upon the literature on relationships amongst variables, CSR is considered as having a positive, significant effect upon the quality of service.

\subsection{Theoretical perspectives on CSR}

\subsubsection{Stakeholder theory}

The intellectual development of the modern theory of stakeholders stems from the seminal work of Freeman (1984). Several definitions have been put forward for identification of stakeholders; these range from a wide framework that regards the stakeholder as a group or individual affected by, or having an interest in, a corporation (Freeman, 1984; Shankman, 1999), to mid-ranging theories with definitions for stakeholders as those individuals or groups that assume a degree of activity that is riskbearing with a corporation (Clarkson, 1995), to narrower perspectives that only have a recognition of stakeholders that are perceived as having a primarily 
economic relationship to a firm (Friedman, 1970). There have also been distinctions made between stakeholders in terms of how important they are for firm survival. Freeman identified primary stakeholders as being in official, formal or contractual relationships with a company, with all other kinds of stakeholders being considered secondary (Shankman, 1999). A distinction was made between involuntary and voluntary stakeholders by Clarkson (1995), with the basis being the acceptance or exposure to activities with a company that are risk-bearing. Regardless of how the stakeholder is defined, the models encompass relationships founded on an exchange that is 2-way; as such, a stakeholder is considered as having an effect upon the activities of a corporation as well as being affected by it. The argument lies in relation to those believing in provision for the discretionary expectations of society. As well as obeying laws and making profits, a firm ought to try and solve or alleviate societal problems. Stakeholder theory commonly advocates this view. It is maintained by this theory that firms ought to consider the impacts of actions upon suppliers, customers, employees, the general public and any other people who may have an interest in or stake in the activities of the firm (Schaefer, 2008; Freeman, Wicks, \& Parmar, 2004; Lee, 2008). Those who support the perspective reason that provision for stakeholder needs ensures the continued success of corporations. Johnson and Johnson is a company that is renowned for exhibiting such a stakeholder view; the credo of the corporation lists its responsibilities as being to customers, its employees, the management, communities and then stakeholders (Seglin, 2002). Stakeholder theory proponents maintain that it is too short-sighted to solely focus on increasing the wealth of shareholders. Based on the perspective of stakeholder theory, CSR increases make a company seem more attractive in the eyes of consumers and, therefore, all firms ought to undertake CSR.

\subsubsection{Problems in the use of stakeholder theory}

a) Denial of fiduciary responsibility - There are a number of significant disadvantages to stakeholder theory. For example, the theory is directly counter to perspectives on corporate governance. As a firm is owned by its shareholders, from the perspective of corporate governance, it ought to be run so that returns can be maximised. The focus of a corporation is transferred by stakeholder theory from the shareholders to stakeholder needs through the implementation of programs of CSR that are unprofitable (Cheers, 2011).

b) Oversimplification - Problems such as pollution and poverty have existed for society for lots of years and if it were simple for them to be solved (in the way that is maintained by stakeholder theory) then remedies would have been found long ago by firms that are profit-seeking that have a focus on providing benefits to society (Karnani, 2010). Lots of businesses, however, have found that pursuance of the welfare of society often results in falls in profit levels.

c) Over-regulation - Stakeholder theory has also been criticised by the argument over overregulation; by this argument, it is maintained that CSR pursuit would tend to lead to social and environmental regulations becoming more rigorous for companies around the world. Such regulations would have a tendency to then hamper undeveloped nations in their quest to keep pace with development within more developed nations (Cheers, 2011).

\subsubsection{The concept of CSR with respect to stakeholder theory}

These days, the concept of CSR is more critically focused on the orientation of corporations that are more strategically focused upon social and environmental concerns. It was considered by Russo and Perrini (2010) that an initial definition for CSR was shown within the study of Carroll (1979) which stressed obligations for businessmen to seek out policies, make decisions and follow courses of action that can be considered desirable from the point of view of the values and objectives of society. This perspective was developed as a response to the increasingly broad range of company activities that were having severe implications for societal welfare and the general conditions of modern living. Nevertheless, the perspective resulted in a kind of scepticism insistent that generating profit was the primary social responsibility of corporations (Friedman, 1962). Nonetheless, many now consider that the sole objective of corporations should no longer be profit; indeed, many folks consider that organisational success should also have a basis in the quality of stakeholder relationships and incorporate perspectives on varied matters of interest for society and the environment (Garriga \& Melé, 2004). In theory, a conclusion arrived at that various actors can influence the performance of organisations. So, appropriate forms of stakeholder management have been seen to be increasingly important. Freeman (2010) defines stakeholders as those groups affected by or able to affect the achievement of the purpose of organisations. Relationships between stakeholders and their significance were stressed by new perspectives; as such, perspectives began to be taken on complex webs of relationships rather than just those dyadic kinds of links between stakeholders and a corporation. Key questions still remain with regard to which stakeholders are associated with a firm and considered from a relationship perspective. Two types of stakeholder legitimacy have been postulated (Phillips, 2003). Firstly, stakeholder identification is considered critical as their various types of relationship to organisations depend, on the whole, upon the community context for organisational operations. Secondly, certain stakeholder types are considered vital for organisations and, therefore, they have a kind of derivative legitimacy derived from moral normative obligations owed to others (Dunham, Freeman, \& Liedtka, 2006). Since stakeholder awareness and attributions of stakeholders were created at the same time as those of the management in relation to company activities of CSR, such awareness has become a main prerequisite so that strategic CSR benefits can be reaped. It is considered imperative that there is a profound understanding of the key issues with regard to CSR communication amongst managers.

\subsubsection{Shareholder theory}

It is proposed by shareholder theory that corporations ought to legally maximise the wealth of shareholders over the long-term (Schaefer, 2008; 
Jensen; 2002). Through the provision of required service or product at a price that is reasonable, a company benefits society. In the language of finance, it is advocated by shareholder theory that companies ought to maximise present value for all cash flows of the future (Danielson, Heck, \& Shaffer, 2008). Once the investment of shareholders has been made, the shareholder depends upon the provision of a return from the company. The CSR critic and manager of mutual funds, Steve Milloy, stated that: "Shareholders do not hire CEOs to be the U.N., to act as a government or to be a charity. They were hired to make money for shareholders. Business is society's wealth-creation machine" (as quoted within Weiss, Kirdahy, \& Kneale, 2008, para. 5). The argument of Milloy has similarity with that of Milton Friedman and Adam Smith for that matter (Cheers, 2011). Making money is the business for business and through serving shareholder needs, a business can generate wealth for the benefit of the wider society. If the bottom line is increased by CSR initiatives, then the implementation of such initiatives is recommended by advocates of shareholder theory. It is, however, wrong to use the money of shareholders in ways that are unprofitable. Regardless of how noble a cause is, it is considered inappropriate to have generosity with the money of others. A number of scholars of shareholder theory believe that there ought to be an abandonment of CSR completely (Cheers, 2011). Whilst, it is conceded that the concept of CSR has raised awareness of the issue of the ethics of business across the world, for some CSR no longer has practicality. For instance, it was argued by Freeman and Liedtka that CSR had by and large failed and ought to be abandoned; they made the claim that there had been a failure to deliver upon promises of creating a 'good society' (Saleem, Kumar, \& Shahid, 2016).

\subsubsection{Problems in using shareholder theory}

a) Externalities - The theory for shareholders also has shortcomings. Within everyday business transactions, there may be the occurrence of externalities, which can be either beneficial or costly to the third party to transactions of a business. For instance, if an industrial company considers opening a plant within the US and it is already known that the proposal would result in the emittance of huge volumes of pollutants likely to cause serious harm to public health in the vicinity and the environment, even though going ahead with the plant could provide greater profits, the benefits would be accompanied by negative externalities for the community (Cheers, 2011). As such, increases to the wealth of shareholders do not always leads to increases in the welfare of stakeholders.

b) The focus upon profit maximisation over the short-term - A further argument put forward against theorists of shareholders argues that focusing upon the wealth of shareholders encourages companies to have a focus upon profit maximisation over the short-term. The shareholder model, however, focuses upon profit maximisation over the long-term (Danielson et al., 2008).

c) Just stakeholder treatment - Similarly, a number of authors have the claim that shareholder theory fails to encourage companies to have just treatment of various stakeholders such as employees and others. There is a simple argument running counter to that perspective since treating stakeholders of a company justly is a kind of prerequisite for that company to be successful. A company that fails to treat employees well is likely to have a workforce that is weak and uncommitted, the result being a loss in profit, for example. As Smith (2003) noted, shareholder theory does not work to prevent companies from making investments in activities that are financially beneficial.

\subsubsection{CSR in relation to shareholder conflict}

So that there can be testing of the presence of shareholder conflict, there can be an analysis of relationships amongst firm characteristics and CSR ratings that have the potential for an impact (Barnea \& Rubin, 2010; Niekerk \& Getz, 2019). Firstly, a claim can be that, were insiders able to obtain unique benefits at the expense of other shareholders, the ownership structure should play a key role in establishing the level of CSR expenditure for a company. Within the literature, it is revealed that, at relatively low levels of ownership, there is insider entrenchment; see, for instance, the study by Morck, Shleifer, and Vishny (1988). Above the entrenchment level of ownership, increases in insider ownership lead to better alignment of insider interests to objectives in relation to maximisation of value for a company. Therefore, if CSR expenditure is set at levels at which the value of the firm is reduced, then there can be an expectation that there could be negative relationships discovered between CSR policies and insider ownership. Secondly, the structure of firm capital may also impact on the degree of conflict in relation to CSR; with high levels of firm interest payments, insiders have limited ability to over-invest in CSR. High debt levels should also induce creditors to take a closer part in monitoring which can aid in the mitigation of such conflicts. It was considered by Barnea and Rubin (2010) that if insider ownership is at high levels, there are low ratings for CSR (implying that CSR expenditure is low); the argument is supported that incremental CSR expenditure does, in the main, lead to reductions in firm value. It was also found by Barnea and Rubin (2010) that if there is an increase in firm leverage of 1 standard deviation then SR definition will decrease in probability by $2.9 \%$; this result supports the hypothesis that high debt levels mean that over-investing in CSR will be more difficult for insiders since they have less available cash. However, in relation to CSR, most literature involves the assumption that different shareholders may have different interests. Affiliated owners are those whose heritage, reputation or identity is in some way related to a firm, whilst non-affiliated owners are that bulk of investors that hold shares in a company as part of a well-diversified, investment portfolio though their relationship to that company extends no further than consideration of their portfolio value.

\subsubsection{Agency theory}

The focus taken by agency theory is upon the agency relationship with regard to certain obligations held by a group or actor (the agent) that need to be fulfilled by way of an economic relationship to another group or actor (the principal). The articulation of this relationship has underlying 
mechanisms in regard to contractual terms between the agent and the principal; so, a firm can be seen as the contractual nexus between agents and principals. In addition, as Bowie and Freeman (1992) noted, dating back as far as the $14^{\text {th }}$ century, there has been explicit outlining of agency relationships within both the common law of England and law of torts. Agency theory essence lies in the assumption that a) the goals or desires of the agent and principal conflict, and $b$ ) that verification of what is being done by an agent is expensive or difficult for the principal (Eisenhardt, 1989); this situation is known as an 'agency problem'. Secondly, since the agent and the principal have varying attitudes in relation to risk, there is a difficulty since, everything else being equal, the agent and principal would prefer differing courses for action; this situation is known as a 'risksharing problem'. The divergences between the interests of the agent and principal that reduce the welfare of the principal are known as the residual loss for agency. Costs of ex-ante bonding can also be incurred by agents; these are measures that are taken in order to show commitment to a principal that also guarantee that there will not be the taking of particular actions in contravention of duties implied within an agency relationship (Hill \& Jones, 1992). The primary theoretical focus within an agency relationship lies with selection of suitable mechanisms for the governance between the agents and the principal in order to ensure that alignment of the interests of the agent and the principal are efficient; the aim is ensuring agents serve interests of principals that, ultimately, minimise agency costs. Both behaviour and outcome-based contracts are used as a way of achieving such an end. As a whole, agency theory is based on relationships mirroring the basic structure of agency of an agent and a principal engaged within behaviour that is cooperative though with different attitudes in relation to risk and with differing goals (Eisenhardt, 1989). The commonest kind of agency within the relationship can be described within the firm view of principal-agent within which company managers are considered to be shareholder agents (principals) who make investments in companies primarily as a wealth enhancing move (Quinn \& Jones, 1995). An assumption underlying this perspective is that, within markets that are efficient, this leads to the social outcome that is most desirable. Accordingly, a most study in relation to agency theory has had a focus upon relationships between managers and owners.

\subsubsection{Problems with the use of agency theory}

The main problems that can crop up in relation to agency relationships are adverse selection and moral hazard with both issues resulting from information asymmetry, with one or more of the parties involved in a transaction having better or more information than other involved parties. A moral hazard can occur if there is inappropriate ex-post behaviour from an agent, i.e. a more informed agent is incentivised to behave in ways that do not align with the interests of the principal. To contrast with that, in models of adverse selection, with information that is ex-ante, an exchange is inappropriate, i.e. a principal is not fully informed of certain characteristics of an agent. The assumption of agency theory is that self-interested individuals are opportunistic (Fama, 1980). So that opportunism can be avoided, there is a need for the agent to be provided with incentives so that they would act in ways that accord with the interests of the principal; rewarding of outcomes or monitoring of behaviour can achieve this (Eisenhardt, 1989); the choice of the two alternatives depends upon their related costs and effectiveness.

\subsubsection{CSR with respect to agency theory}

CSR is defined by the World Bank as "the commitment of business to contribute to sustainable economic development by working with employees, their families, the local community and society at large to improve their lives in ways that are good for business and for development". So, CSR can be considered as an agent-principal relationship wherein, in general, business enterprises can be considered as either principals or agents depending upon the relationship character (Germanova, 2008; Ali, Frynas, \& Mahmood, 2017).

\subsubsection{Business enterprise as a form of an agent with respect to types of CSR}

Within a relationship of agent-principal, a business enterprise may be seen as the agent if it has relationships with a variety of stakeholders (principal groups) that force it to act in socially responsible ways with the integration of social and environmental concerns within day-to-day business operations. Stakeholders may have the power to help or hinder a business plan (Germanova, 2008). Several aspects of the relationships can be appreciated as follows:

a) Local community and the wider society. Behaviour within society is influenced by social traditions, fundamental values, the culture and the laws that are at work (Mäntysaari, 2008). The local community may influence a company business strategy by way of its own priorities and its powerful voice forcing due consideration to be given to societal agendas, and ensuring a company acts in ways that have a greater degree of social responsibility;

b) Employees. Employees are a key asset for any firm and so they too may be seen as being key principals. The implementation for strategies of CSR by firms can be done with the focus on retaining employees, ensuring improvements in their work environment in relation to health and safety matters, offering support for the career development of personnel, and the respecting of human rights and labour standards and so forth (Germanova, 2008);

c) Customers and the public. Customers may act as key drivers forcing a firm to adopt enhanced values with respect to society and the environment within business operations. In fact, sometimes, there can be reliance upon customers forcing company managers to act in particular ways (Mäntysaari, 2008).

d) State. Responsibility for developing policies and encouraging mechanisms to be adopted for improving business environments and encouragement of CSR within businesses ultimately lies with the state. Laws can be amended by the state 
which can also adopt national CSR strategies and nominate governmental representatives for CSR (Germanova, 2008). It is debatable whether or not CSR ought to be left to businesses or whether or not governments have a willingness to fully engage with the issue (Germanova, 2008). In practical terms, if there is a lack of governmental rules, companies may feel compelled to take civic action to fill the void that has been left.

\section{RESEARCH METHODOLOGY}

This research has adopted a number of survey items that were developed and validated within previous research in order to measure perceived levels for personal relevance for CSR, the level of commitment to CSR, the satisfaction of customers, quality of service, loyalty and trust. Hence, there were three main groups of respondents, i.e. customers of LTT, Almadar Aljadid and Libyana (AlMutairi \& Yen, 2017). Of the 230 questionnaires that were distributed, a total of 182 were returned. So that the robustness can be increased in the analysis, 28 of the questionnaires were considered unusable as they were incomplete or filled in with an obvious bias. So, there were 154 responses used within the final analysis; the implication, then, is that there was a response rate of around $66.9 \%$.

\section{RESULTS AND DISCUSSION}

Faced with fierce competition within the current marketplace for telecommunications, many different marketing strategies have been adopted for planning and implementation by service providers. However, the range of activities for the social responsibility of customers can disturb consumers (Pérez \& Rodríguez del Bosque, 2015b). Evidence also shows that consumers tend to go with other competitors if they become dissatisfied with the quality of service. The social responsibilities of customers could be a prime way for providers of services to build loyalty amongst customers and retain customers. Lots of empirical studies have put forward evidence that the social responsibilities of customers have an impact upon behavioural loyalty, and that this has an effect upon customer retention (Pérez \& Rodríguez del Bosque, 2015b). So, it is a very significant matter to have a sound awareness of the consumers to be targeted and to build good relationships with them. For the providers of telecommunication services, a key challenge is the attracting of more customers, focusing on building good quality relationships with them to make them feel satisfied and trusting and bit by bit earn their loyalty.

Within this section, there is a presentation of the findings of the survey and the discussion of them. There is a concentration upon participant group attitudes, in general, with regard to the telecom sector in Libya and, in particular, there is an analysis of perspectives of targeted groups that were sampled. The section is split into two main parts. Firstly, there is a part that reports the demography of the respondents. Then, there is the analysis of the statistics through the use of the SPSS package, commonly used within the social sciences. The analysis is of respondent group attitudes with respect to the following: Activities of CSR with respect to enhancement of satisfaction in regard to the Libyan Telecom Sector (LTS); the impact of activities of CSR with regard to loyalty of customers with regard to the LTS; the influence of trust upon loyalty of customers with regard to the LTS; and the influence of quality of service upon loyalty of customers with regard to the LTS.

\subsection{Demography of respondents}

The aim of this section is the provision of general background information about the groups of participants who took part in the survey questionnaire. This section also shows details about the demographic profiles of the 3 participant groups based upon their age, education level and gender.

Statistics about the gender of the participants are presented within Table 1. A third of the participants were female, the rest male. Of the male participants, 31\% of them used LTT, 32\% used AAJ and $36 \%$ used Libyana. Correspondingly, 33\% of females used LTT, 25\% of females used AAJ and 42\% of females used Libyana. The suggestion from these statistics is that there is sufficient distribution amongst the participants for them to appreciate the importance and purposes of the issue under examination.

Table 1. Cross-tabulation for companies and gender

\begin{tabular}{|c|c|c|c|c|c|c|}
\hline \multirow{3}{*}{ Companies } & \multicolumn{4}{|c|}{ What is your gender? } & \multirow{2}{*}{\multicolumn{2}{|c|}{ Total }} \\
\hline & \multicolumn{2}{|c|}{ Male } & \multicolumn{2}{|c|}{ Female } & & \\
\hline & $F$ & $\%$ & $F$ & $\%$ & $F$ & $\%$ \\
\hline Gender & 102 & $66.2 \%$ & 52 & $33.7 \%$ & 154 & $100 \%$ \\
\hline Libya Telecom \& Tech & 32 & $31 \%$ & 17 & $33 \%$ & 49 & $32 \%$ \\
\hline Libyan & 37 & $36 \%$ & 22 & $42 \%$ & 59 & $38 \%$ \\
\hline Almadar Aljadid & 33 & $32 \%$ & 13 & $25 \%$ & 46 & $30 \%$ \\
\hline Total & 102 & $100 \%$ & 52 & $100 \%$ & 154 & $100 \%$ \\
\hline
\end{tabular}

Table 2 below shows the research participants with respect to age. It is shown from the results that over half of all the participants were aged between 18 and 25 years of age, i.e. a combination of those between 18 and 25 years of age (28.6\%) and those between 26 and 35 years of age (24.7\%). Of those aged between 18 and 25 years of age, the most were utilising Libyana (45\%); the remaining 55\% were split equally between those using AAJ and those using
LTT. Of those in the age group of between 26 and 35 years of age, $42 \%$ were using AAJ, with the remaining users split between use of LTT and Libyana at approximately $29 \%$ each. These figures show that most participants with from 18 to 35 years of age are attracted to the new technologies and provision of extra services for users. They would be enabled to take in and appreciate the objectives of the research so that they could participate effectively within it. 
Table 2. Cross-tabulation for companies and age

\begin{tabular}{|c|c|c|c|c|c|c|c|c|c|c|c|c|c|c|}
\hline \multirow{3}{*}{ Companies } & \multicolumn{12}{|c|}{ What is your age? } & \multirow{2}{*}{\multicolumn{2}{|c|}{ Total }} \\
\hline & \multicolumn{2}{|c|}{ Below 18 years } & \multicolumn{2}{|c|}{$18-25$ years } & \multicolumn{2}{|c|}{ 26-35 years } & \multicolumn{2}{|c|}{$36-45$ years } & \multicolumn{2}{|c|}{$46-55$ years } & \multicolumn{2}{|c|}{ More than 55 years } & & \\
\hline & $F$ & $\%$ & $F$ & $\%$ & $F$ & $\%$ & $F$ & $\%$ & $F$ & $\%$ & $F$ & $\%$ & $F$ & $\%$ \\
\hline Age & 11 & $7.1 \%$ & 44 & $28.6 \%$ & 38 & $24.7 \%$ & 26 & $17 \%$ & 16 & $10.2 \%$ & 19 & $12.3 \%$ & 154 & $100 \%$ \\
\hline $\begin{array}{l}\text { Libya Telecom } \\
\& \text { Tech }\end{array}$ & 7 & $64 \%$ & 12 & $27 \%$ & 11 & $29 \%$ & 7 & $27 \%$ & 7 & $44 \%$ & 5 & $26 \%$ & 49 & $32 \%$ \\
\hline Libyan & 2 & $18 \%$ & 20 & $45 \%$ & 11 & $29 \%$ & 11 & $42 \%$ & 5 & $31 \%$ & 10 & $53 \%$ & 59 & $38 \%$ \\
\hline $\begin{array}{l}\text { Almadar } \\
\text { Aljadid }\end{array}$ & 2 & $18 \%$ & 12 & $27 \%$ & 16 & $42 \%$ & 8 & $31 \%$ & 4 & $25 \%$ & 4 & $21 \%$ & 46 & $30 \%$ \\
\hline Total & 11 & $100 \%$ & 44 & $100 \%$ & 38 & $100 \%$ & 26 & $100 \%$ & 16 & $100 \%$ & 19 & $100 \%$ & 154 & $100 \%$ \\
\hline
\end{tabular}

Table 3 below shows participant education levels in relation to the three companies targeted. Most participants were holders of bachelor's degrees and higher degrees were held by $14.3 \%$ (master's) and $13 \%$ (doctorate). Of the holders of bachelor's degrees, 36\% used Libyana and 41\% used AAJ. Of the holders of master's and doctorate level qualifications, 50\% used Libyana. LTT was used by $83.3 \%$ of those with High Diploma level qualifications.

Table 3. Cross-tabulation for companies and education level

\begin{tabular}{|c|c|c|c|c|c|c|c|c|c|c|}
\hline \multirow{3}{*}{ Companies } & \multicolumn{8}{|c|}{ Please indicate your highest education level achieved } & \multirow{2}{*}{\multicolumn{2}{|c|}{ Total }} \\
\hline & \multicolumn{2}{|c|}{ High Diploma } & \multicolumn{2}{|c|}{ Bachelor } & \multicolumn{2}{|c|}{ Masters } & \multicolumn{2}{|c|}{ Doctorate } & & \\
\hline & $F$ & $\%$ & $F$ & $\%$ & $\boldsymbol{F}$ & $\%$ & $\boldsymbol{F}$ & $\%$ & $F$ & $\%$ \\
\hline Level of Education & 12 & $7.8 \%$ & 100 & $64.9 \%$ & 22 & $14.3 \%$ & 20 & $13 \%$ & 154 & $100 \%$ \\
\hline Libya Telecom \& Tech & 10 & $83 \%$ & 23 & $23 \%$ & 10 & $45 \%$ & 6 & $30 \%$ & 49 & $32 \%$ \\
\hline Libyan & 2 & $17 \%$ & 36 & $36 \%$ & 11 & $50 \%$ & 10 & $50 \%$ & 59 & $38 \%$ \\
\hline Almadar Aljadid & 0 & $0 \%$ & 41 & $41 \%$ & 1 & $5 \%$ & 4 & $20 \%$ & 46 & $30 \%$ \\
\hline Total & 12 & $100 \%$ & 100 & $100 \%$ & 22 & $100 \%$ & 20 & $100 \%$ & 154 & $100 \%$ \\
\hline
\end{tabular}

\subsection{Statistical analysis}

Following the presentation of respondent profiles in terms of demography, to achieve the objectives of the research, the aim of this section is the provision of statistical analyses for the remainder of the questionnaire. With this section, there is a provision of both inferential and descriptive statistics aimed at answering the questions of the research. The oneway ANOVA test was selected as it was appropriate for handling the variables of the study. The structure of this section is based on a number of themes as follows: the enhancement of satisfaction within the LTS through activities of CSR; the influence of activities of CSR upon the loyalty of customers with the LTS; the influence of trust upon loyalties of customer within the LTS; and the influence of quality of service upon loyalty of customer with the LTS.

\subsubsection{CSR activities and enhancement of satisfaction within the LTS}

Table 4 below helps to highlight the investigation findings in relation to respondent opinions in regard to the evaluation of activities of CSR and enhancement of satisfaction within the LTS. Four different statements were put together in order for the variables to be tested employing a Likert scale with a range from one for disagree strongly to five for agree strongly. The mean scores demonstrated within Table 4 show fluctuation between values of 3.81 and 4.44 which shows that the respondents did, on average, show consensus that activities for CSR serve to enhance the levels of satisfaction felt within the LTS. In order to have an analysis with more detail, a cross-tabulation was independently undertaken for all of the respondent groups. From the frequencies within Table 4 , it is noticeable that, generally, research participant group responses have a direction that is highly consistent of the general perspective of participants shown with Table 4 below. There was the running of a one-way ANOVA test in order to identify if any differences were evident in customer perspectives within the LTS in the evaluation of activities for CSR with respect to enhancement of satisfaction in them. The one-way ANOVA test outcomes highlighted that no significant difference in statistics with regard to participant groups with regard to the attitude of customers of LTS, with at P >0.05, F $(2,151)=$ between 0.871 and 1.435 .

The survey questionnaire findings, with regard to the construct for activities for CSR and the enhancement of satisfaction in LTS, show that most participants were in agreement over the fact that there was a major impact of CSR upon satisfaction within the LTS. So, therefore, the results overall have consistency with the findings of Boshoff and Gray (2004) that underlined that it is not inherent for satisfaction to be present in relation to a service or product but rather, primarily, satisfaction consists in perceptions of consumers of service or product attributes as the individual experiences them. So, the same service encounter or experience will lead to different consumers expressing differing satisfaction levels (Ueltschy, Laroche, Eggert, \& Bindl, 2007).

Within the literature on marketing, there is a recognition that customer satisfaction is a key corporate strategy aspect (Fornell, Mithas, Morgeson, \& Krishnan, 2006) as well as a key driver for market value and the long-term profitability of a firm (Oh, Hong, \& Kim, 2013). In particular, an image in relation to CSR has an impact on affective customer responses, such as the identification of a customer with a sense of satisfaction. Consequently, affective responses serve to determine the behaviour of customers in relation to repurchasing and 
recommendation. Furthermore, Fortune 500 companies were investigated by Luo and Bhattacharya (2006) and they found a direct relationship between CSR and the satisfaction of customers; the study highlighted that there is not always a straightforward relationship between satisfaction and CSR (Luo \& Bhattacharya, 2006). Pomering and Dolnicar (2006) undertook a study that showed that customers could have a preference for initiatives that are more self-serving. So, in some cases, companies may, in choosing to pursue programs for CSR with an expectation of an associated improvement to customer satisfaction, misdirect scarce resources to causes that are not beneficial to the majority of their customers. So, there is an expectation that there is a positive relationship of CSR to the satisfaction of customers.

Table 4. Cross-tabulation for companies and satisfaction

\begin{tabular}{|c|c|c|c|c|c|c|c|c|c|c|c|c|c|c|c|}
\hline & \multirow[t]{2}{*}{ Mean } & \multirow{2}{*}{$\begin{array}{l}\text { Std. } \\
\text { Dev }\end{array}$} & \multicolumn{2}{|c|}{$\begin{array}{l}\text { Strongly } \\
\text { disagree }\end{array}$} & \multicolumn{2}{|c|}{ Disagree } & \multicolumn{2}{|c|}{ Neutral } & \multicolumn{2}{|c|}{ Agree } & \multicolumn{2}{|c|}{$\begin{array}{c}\text { Strongly } \\
\text { agree }\end{array}$} & \multicolumn{2}{|c|}{ Total } \\
\hline & & & & $F$ & $\%$ & $F$ & $\%$ & $F$ & $\%$ & $F$ & $\%$ & $F$ & $\%$ & $F$ & $\%$ \\
\hline \multirow{4}{*}{$\begin{array}{l}\text { I am satisfied with the } \\
\text { overall service quality } \\
\text { offered by this } \\
\text { operator. }\end{array}$} & LTT & \multirow{4}{*}{4.44} & \multirow{4}{*}{1.07} & 1 & $17 \%$ & 5 & $71 \%$ & 6 & $55 \%$ & 6 & $32 \%$ & 31 & $28 \%$ & 49 & $32 \%$ \\
\hline & LY & & & 2 & $33 \%$ & 2 & $29 \%$ & 5 & $45 \%$ & 7 & $37 \%$ & 43 & $39 \%$ & 59 & $38 \%$ \\
\hline & AAJ & & & 3 & $50 \%$ & 0 & $0 \%$ & 0 & $0 \%$ & 6 & $32 \%$ & 37 & $33 \%$ & 46 & $30 \%$ \\
\hline & Total & & & 6 & $100 \%$ & 7 & $100 \%$ & 11 & $100 \%$ & 19 & $100 \%$ & 111 & $100 \%$ & 154 & $100 \%$ \\
\hline \multirow{4}{*}{$\begin{array}{l}\text { I am satisfied with the } \\
\text { professional } \\
\text { competence of this } \\
\text { operator. }\end{array}$} & LTT & \multirow{4}{*}{4.20} & \multirow{4}{*}{1.22} & 1 & $14 \%$ & 5 & $38 \%$ & 9 & $45 \%$ & 6 & $38 \%$ & 28 & $29 \%$ & 49 & $32 \%$ \\
\hline & LY & & & 4 & $57 \%$ & 7 & $54 \%$ & 4 & $20 \%$ & 8 & $50 \%$ & 36 & $37 \%$ & 59 & $38 \%$ \\
\hline & AAJ & & & 2 & $29 \%$ & 1 & $8 \%$ & 7 & $35 \%$ & 2 & $13 \%$ & 34 & $35 \%$ & 46 & $30 \%$ \\
\hline & Total & & & 7 & $100 \%$ & 13 & $100 \%$ & 20 & $100 \%$ & 16 & $100 \%$ & 98 & $100 \%$ & 154 & $100 \%$ \\
\hline \multirow{4}{*}{$\begin{array}{l}\text { I am satisfied with the } \\
\text { performance of the } \\
\text { frontline employees of } \\
\text { this operator. }\end{array}$} & LTT & \multirow{4}{*}{4.10} & \multirow{4}{*}{1.16} & 0 & $0 \%$ & 4 & $22 \%$ & 11 & $46 \%$ & 9 & $38 \%$ & 25 & $29 \%$ & 49 & $32 \%$ \\
\hline & LY & & & 2 & $67 \%$ & 8 & $44 \%$ & 10 & $42 \%$ & 10 & $42 \%$ & 29 & $34 \%$ & 59 & $38 \%$ \\
\hline & AAJ & & & 1 & $33 \%$ & 6 & $33 \%$ & 3 & $13 \%$ & 5 & $21 \%$ & 31 & $36 \%$ & 46 & $30 \%$ \\
\hline & Total & & & 3 & $100 \%$ & 18 & $100 \%$ & 24 & $100 \%$ & 24 & $100 \%$ & 85 & $100 \%$ & 154 & $100 \%$ \\
\hline \multirow{4}{*}{$\begin{array}{l}\text { I am comfortable } \\
\text { about the relationship } \\
\text { with this operator. }\end{array}$} & LTT & \multirow{4}{*}{3.81} & \multirow{4}{*}{0.98} & 0 & $0 \%$ & 1 & $6 \%$ & 14 & $41 \%$ & 22 & $36 \%$ & 12 & $29 \%$ & 49 & $32 \%$ \\
\hline & LY & & & 1 & $100 \%$ & 9 & $53 \%$ & 11 & $32 \%$ & 25 & $41 \%$ & 13 & $32 \%$ & 59 & $38 \%$ \\
\hline & AAJ & & & 0 & $0 \%$ & 7 & $41 \%$ & 9 & $26 \%$ & 14 & $23 \%$ & 16 & $39 \%$ & 46 & $30 \%$ \\
\hline & Total & & & 1 & $100 \%$ & 17 & $100 \%$ & 34 & $100 \%$ & 61 & $100 \%$ & 41 & $100 \%$ & 154 & $100 \%$ \\
\hline
\end{tabular}

Note: Libya Telecom \& Tech - LTT, Libyan - LY, Almadar Aljadid - AAJ

Likert scale: 1 = Strongly disagree, $2=$ Disagree, $3=$ Neutral, $4=$ Agree, $5=$ Strongly agree

\subsubsection{Impact of CSR activities upon customer loyalties within the LTS}

Within Table 5 below, the investigation findings are highlighted with regard to respondent opinion overevaluation of activities for CSR and their impact upon loyalties of customers with respect to the LTS. A total of 6 statements were put together in order to examine variables through the use of the Likert scale with a range from one for disagree strongly to five for agree strongly. The mean scores demonstrated within Table 5 show fluctuation between 3.64 and 3.10 which shows that, on average, respondents showed consensus with respect to activities for CSR and their bearing upon customer loyalties with the LTS. For a deeper analysis, cross-tabulation was undertaken independently for all respondent groups. From the frequencies shown within Table 5 , it may be seen that, generally, participant group responses had a direction that had a high level of consistency with the general participant view shown with Table 5 below. The application of the one-way ANOVA test was done for identification of variations amongst the customers of LTS with respect to the evaluation of the impact of activities for CSR upon the loyalty of customers with the LTS. The oneANOVA test outcomes highlighted that no significant statistical differences existed with regard to groups of participants with respect to the impact of activities for CSR on the loyalty of customers with respect to LTS, where $\mathrm{p}>0.05$ and $\mathrm{F}(2,151)=$ between 0.854 and 2.204. The survey questionnaire findings with regard to the construct for activities of CSR and their impact upon the loyalty of customers with the LTS show that most participants were in agreement with the proposition that there is a positive interlinkage between CSR and loyalty of customers with the LTS. So, therefore, the results overall have consistency with studies done previously as loyalty of customer is seen as an essential objective for the growth and survival of a firm; the building of a customer base that is loyal is not only considered a key goal in marketing terms (Mandhachitara \& Poolthong, 2011), but it can also be considered as a vital foundation for the development of a competitive advantage that can be sustained (Dick \& Basu, 1994). Having an understanding of the retention or cultivation of loyalty is, therefore, considered as a vital aspect to the delivery of corporate profitability over the longterm (Chiou \& Droge, 2006) since retention of customers can lead to increased profits during the course of their lives (Lemon, White, \& Winer, 2002). Previous research has shown CSR to have a key impact upon the attitudes of consumers, their satisfaction, their loyalty, their purchasing intentions and upon consumer-company identification. The indication from initial studies is that the commitment of a firm to initiatives for CSR is taken into account by consumers during their evaluation of companies and the products that they offer (Öberseder, Schlegelmilch, \& Murphy, 2013). There is widespread agreement that the satisfaction of customers leads to purchasing intention, word of mouth and their retention (Anderson \& Mittal, 2000); so, there is an expectation that there is a positive relationship of CSR and satisfaction of customers with the loyalty of customers. 
Table 5. Cross-tabulation for companies and the impact of CSR activities upon customer loyalties within the LTS

\begin{tabular}{|c|c|c|c|c|c|c|c|c|c|c|c|c|c|c|c|}
\hline & \multirow[t]{2}{*}{ Mean } & \multirow{2}{*}{$\begin{array}{l}\text { Std. } \\
\text { Dev }\end{array}$} & \multicolumn{2}{|c|}{$\begin{array}{l}\text { Strongly } \\
\text { disagree }\end{array}$} & \multicolumn{2}{|c|}{ Disagree } & \multicolumn{2}{|c|}{ Neutral } & \multicolumn{2}{|c|}{ Agree } & \multicolumn{2}{|c|}{$\begin{array}{c}\text { Strongly } \\
\text { agree }\end{array}$} & \multicolumn{2}{|c|}{ Total } \\
\hline & & & & $F$ & $\%$ & $F$ & $\%$ & $F$ & $\%$ & $F$ & $\%$ & $F$ & $\%$ & $F$ & $\%$ \\
\hline \multirow{4}{*}{$\begin{array}{l}\text { I intend to continue } \\
\text { using mobile } \\
\text { services from this } \\
\text { operator for a long } \\
\text { time. }\end{array}$} & LTT & \multirow{4}{*}{3.10} & \multirow{4}{*}{1.39} & 11 & $37 \%$ & 2 & $10 \%$ & 16 & $42 \%$ & 16 & $44 \%$ & 4 & $13 \%$ & 49 & $32 \%$ \\
\hline & LY & & & 13 & $43 \%$ & 12 & $60 \%$ & 11 & $29 \%$ & 13 & $36 \%$ & 10 & $33 \%$ & 59 & $38 \%$ \\
\hline & AAJ & & & 6 & $20 \%$ & 6 & $30 \%$ & 11 & $29 \%$ & 7 & $19 \%$ & 16 & $53 \%$ & 46 & $30 \%$ \\
\hline & Total & & & 30 & $100 \%$ & 20 & $100 \%$ & 38 & $100 \%$ & 36 & $100 \%$ & 30 & $100 \%$ & 154 & $100 \%$ \\
\hline \multirow{4}{*}{$\begin{array}{l}\text { If I want to change a } \\
\text { new telecom service, } \\
\text { I am willing to } \\
\text { continue selecting } \\
\text { this operator. }\end{array}$} & LTT & \multirow{4}{*}{3.52} & \multirow{4}{*}{0.98} & 0 & $0 \%$ & 9 & $0 \%$ & 19 & $0 \%$ & 15 & $0 \%$ & 6 & $0 \%$ & 49 & $0 \%$ \\
\hline & LY & & & 0 & $0 \%$ & 11 & $0 \%$ & 19 & $0 \%$ & 14 & $0 \%$ & 15 & $0 \%$ & 59 & $0 \%$ \\
\hline & AAJ & & & 0 & $0 \%$ & 3 & $0 \%$ & 22 & $0 \%$ & 10 & $0 \%$ & 11 & $0 \%$ & 46 & $0 \%$ \\
\hline & Total & & & 0 & $100 \%$ & 23 & $100 \%$ & 60 & $100 \%$ & 39 & $100 \%$ & 32 & $100 \%$ & 154 & $100 \%$ \\
\hline \multirow{4}{*}{$\begin{array}{l}\text { Even if another } \\
\text { operator' price is } \\
\text { lower; I will go on } \\
\text { using this provider. }\end{array}$} & LTT & \multirow{4}{*}{4.60} & \multirow{4}{*}{0.76} & 0 & $0 \%$ & 1 & $50 \%$ & 6 & $43 \%$ & 10 & $43 \%$ & 32 & $28 \%$ & 49 & $32 \%$ \\
\hline & LY & & & 1 & $100 \%$ & 0 & $0 \%$ & 3 & $21 \%$ & 9 & $39 \%$ & 46 & $40 \%$ & 59 & $38 \%$ \\
\hline & $\mathrm{AAJ}$ & & & 0 & $0 \%$ & 1 & $50 \%$ & 5 & $36 \%$ & 4 & $17 \%$ & 36 & $32 \%$ & 46 & $30 \%$ \\
\hline & Total & & & 1 & $100 \%$ & 2 & $100 \%$ & 14 & $100 \%$ & 23 & $100 \%$ & 114 & $100 \%$ & 154 & $100 \%$ \\
\hline \multirow{4}{*}{$\begin{array}{l}\text { I am willing to say } \\
\text { positive things about } \\
\text { this operator to } \\
\text { other people. }\end{array}$} & LTT & \multirow{4}{*}{4.64} & \multirow{4}{*}{0.69} & 0 & $0 \%$ & 1 & $0 \%$ & 6 & $0 \%$ & 10 & $0 \%$ & 32 & $0 \%$ & 49 & $0 \%$ \\
\hline & LY & & & 0 & $0 \%$ & 0 & $0 \%$ & 3 & $0 \%$ & 9 & $0 \%$ & 47 & $0 \%$ & 59 & $0 \%$ \\
\hline & AAJ & & & 0 & $0 \%$ & 1 & $0 \%$ & 4 & $0 \%$ & 4 & $0 \%$ & 37 & $0 \%$ & 46 & $0 \%$ \\
\hline & Total & & & 0 & $100 \%$ & 2 & $100 \%$ & 13 & $100 \%$ & 23 & $100 \%$ & 116 & $100 \%$ & 154 & $100 \%$ \\
\hline \multirow{4}{*}{$\begin{array}{l}\text { I will encourage } \\
\text { friends and relatives } \\
\text { to use the services } \\
\text { offered by this } \\
\text { operator. }\end{array}$} & LTT & \multirow{4}{*}{3.10} & \multirow{4}{*}{1.39} & 11 & $0 \%$ & 2 & $0 \%$ & 16 & $0 \%$ & 16 & $0 \%$ & 4 & $0 \%$ & 49 & $0 \%$ \\
\hline & LY & & & 13 & $0 \%$ & 12 & $0 \%$ & 11 & $0 \%$ & 13 & $0 \%$ & 10 & $0 \%$ & 59 & $0 \%$ \\
\hline & AAJ & & & 6 & $0 \%$ & 6 & $0 \%$ & 11 & $0 \%$ & 7 & $0 \%$ & 16 & $0 \%$ & 46 & $0 \%$ \\
\hline & Total & & & 30 & $100 \%$ & 20 & $100 \%$ & 38 & $100 \%$ & 36 & $100 \%$ & 30 & $100 \%$ & 154 & $100 \%$ \\
\hline \multirow{4}{*}{$\begin{array}{l}\text { To me, this operator } \\
\text { clearly is able to } \\
\text { provide exceptional } \\
\text { services in } \\
\text { communications. }\end{array}$} & LTT & \multirow{4}{*}{3.52} & \multirow{4}{*}{0.98} & 0 & $0 \%$ & 9 & $0 \%$ & 19 & $0 \%$ & 15 & $0 \%$ & 6 & $0 \%$ & 49 & $0 \%$ \\
\hline & LY & & & 0 & $0 \%$ & 11 & $0 \%$ & 19 & $0 \%$ & 14 & $0 \%$ & 15 & $0 \%$ & 59 & $0 \%$ \\
\hline & AAJ & & & 0 & $0 \%$ & 3 & $0 \%$ & 22 & $0 \%$ & 10 & $0 \%$ & 11 & $0 \%$ & 46 & $0 \%$ \\
\hline & Total & & & 0 & $100 \%$ & 23 & $100 \%$ & 60 & $100 \%$ & 39 & $100 \%$ & 32 & $100 \%$ & 154 & $100 \%$ \\
\hline
\end{tabular}

Note: Libya Telecom \& Tech - LTT, Libyan - LY, Almadar Aljadid - AAJ

Likert scale: 1 = Strongly disagree, 2 = Disagree, 3 = Neutral, $4=$ Agree, $5=$ Strongly agree

4.2.3. The impacts of trust upon customer loyalties within the LTS

Table 6 below highlights findings in regard to the investigation of respondent opinion over-evaluation of the impact of trust upon loyalty of customers with the LTS. A total of 5 statements were put together in order for the variables to be tested through the use of the Likert scale with a range from one for disagree strongly to five for agree strongly. The mean scores shown within Table 6 have a fluctuation between 4.26 and 3.62 which indicates that, on average, the respondents show consensus with regard to the influence of trust upon the loyalty of customers with regard to the LTS. For a deeper analysis, cross-tabulation was undertaken independently for all respondent groups. From the frequencies shown in Table 6 , it may be seen that, generally, participant group responses had a direction with a high level of consistency with the general participant view shown within Table 6 . In order to identify if any variations exist within perspectives of the customers of LTS, there was a running of a one-way ANOVA test; the outcomes of the testing highlighted that no significant statistical differences existed with regard to participant groups with respect to the influence of trust upon the loyalty of customers with the LTS, where $\mathrm{p}>0.05$, $\mathrm{F}(2,151)=$ between 0.762 and 1.094 .

Table 6. Cross-tabulation for companies and the impact of trust upon customer loyalties within the LTS

\begin{tabular}{|c|c|c|c|c|c|c|c|c|c|c|c|c|c|c|c|}
\hline & \multirow[t]{2}{*}{ Mean } & \multirow{2}{*}{$\begin{array}{l}\text { Std. } \\
\text { Dev }\end{array}$} & \multicolumn{2}{|c|}{$\begin{array}{l}\text { Strongly } \\
\text { disagree }\end{array}$} & \multicolumn{2}{|c|}{ Disagree } & \multicolumn{2}{|c|}{ Neutral } & \multicolumn{2}{|c|}{ Agree } & \multicolumn{2}{|c|}{$\begin{array}{c}\text { Strongly } \\
\text { agree }\end{array}$} & \multicolumn{2}{|c|}{ Total } \\
\hline & & & & $F$ & $\%$ & $F$ & $\%$ & $F$ & $\%$ & $F$ & $\%$ & $F$ & $\%$ & $F$ & $\%$ \\
\hline \multirow{4}{*}{$\begin{array}{l}\text { This operator is } \\
\text { reliable because it is } \\
\text { mainly concerned } \\
\text { with the consumers' } \\
\text { interests. }\end{array}$} & LTT & \multirow{4}{*}{4.10} & \multirow{4}{*}{1.06} & 0 & $0 \%$ & 6 & $38 \%$ & 9 & $30 \%$ & 12 & $40 \%$ & 22 & $28 \%$ & 49 & $32 \%$ \\
\hline & LY & & & 0 & $0 \%$ & 8 & $50 \%$ & 4 & $13 \%$ & 13 & $43 \%$ & 34 & $44 \%$ & 59 & $38 \%$ \\
\hline & AAJ & & & 0 & $0 \%$ & 2 & $13 \%$ & 17 & $57 \%$ & 5 & $17 \%$ & 22 & $28 \%$ & 46 & $30 \%$ \\
\hline & Total & & & 0 & $100 \%$ & 16 & $100 \%$ & 30 & $100 \%$ & 30 & $100 \%$ & 78 & $100 \%$ & 154 & $100 \%$ \\
\hline \multirow{4}{*}{$\begin{array}{l}\text { The billing system of } \\
\text { this operator is } \\
\text { honest. }\end{array}$} & LTT & \multirow{4}{*}{4.20} & \multirow{4}{*}{0.94} & 1 & $33 \%$ & 4 & $50 \%$ & 2 & $15 \%$ & 24 & $39 \%$ & 18 & $26 \%$ & 49 & $32 \%$ \\
\hline & LY & & & 2 & $67 \%$ & 3 & $38 \%$ & 5 & $38 \%$ & 23 & $38 \%$ & 26 & $38 \%$ & 59 & $38 \%$ \\
\hline & $\mathrm{AAJ}$ & & & 0 & $0 \%$ & 1 & $13 \%$ & 6 & $46 \%$ & 14 & $23 \%$ & 25 & $36 \%$ & 46 & $30 \%$ \\
\hline & Total & & & 3 & $100 \%$ & 8 & $100 \%$ & 13 & $100 \%$ & 61 & $100 \%$ & 69 & $100 \%$ & 154 & $100 \%$ \\
\hline \multirow{4}{*}{$\begin{array}{l}\text { The reputation of } \\
\text { this operator is } \\
\text { trustworthy. }\end{array}$} & LTT & \multirow{4}{*}{4.10} & \multirow{4}{*}{1.06} & 0 & $0 \%$ & 6 & $38 \%$ & 9 & $30 \%$ & 12 & $40 \%$ & 22 & $28 \%$ & 49 & $32 \%$ \\
\hline & $\mathrm{LY}$ & & & 0 & $0 \%$ & 8 & $50 \%$ & 4 & $13 \%$ & 13 & $43 \%$ & 34 & $44 \%$ & 59 & $38 \%$ \\
\hline & $\mathrm{AAJ}$ & & & 0 & $0 \%$ & 2 & $13 \%$ & 17 & $57 \%$ & 5 & $17 \%$ & 22 & $28 \%$ & 46 & $30 \%$ \\
\hline & Total & & & 0 & $100 \%$ & 16 & $100 \%$ & 30 & $100 \%$ & 30 & $100 \%$ & 78 & $100 \%$ & 154 & $100 \%$ \\
\hline \multirow{4}{*}{$\begin{array}{l}\text { The policies and } \\
\text { practices of this } \\
\text { operator are reliable. }\end{array}$} & LTT & \multirow{4}{*}{4.26} & \multirow{4}{*}{0.95} & 1 & $33 \%$ & 4 & $50 \%$ & 2 & $15 \%$ & 24 & $39 \%$ & 18 & $26 \%$ & 49 & $32 \%$ \\
\hline & LY & & & 2 & $67 \%$ & 3 & $38 \%$ & 5 & $38 \%$ & 23 & $38 \%$ & 26 & $38 \%$ & 59 & $38 \%$ \\
\hline & $\mathrm{AAJ}$ & & & 0 & $0 \%$ & 1 & $13 \%$ & 6 & $46 \%$ & 14 & $23 \%$ & 25 & $36 \%$ & 46 & $30 \%$ \\
\hline & Total & & & 3 & $100 \%$ & 8 & $100 \%$ & 13 & $100 \%$ & 61 & $100 \%$ & 69 & $100 \%$ & 154 & $100 \%$ \\
\hline \multirow{4}{*}{$\begin{array}{l}\text { The service process } \\
\text { provided by this } \\
\text { operator is secure. }\end{array}$} & LTT & \multirow{4}{*}{3.62} & \multirow{4}{*}{1.09} & 2 & $40 \%$ & 5 & $23 \%$ & 4 & $11 \%$ & 29 & $52 \%$ & 9 & $25 \%$ & 49 & $32 \%$ \\
\hline & LY & & & 0 & $0 \%$ & 13 & $59 \%$ & 14 & $40 \%$ & 15 & $27 \%$ & 17 & $47 \%$ & 59 & $38 \%$ \\
\hline & $\mathrm{AAJ}$ & & & 3 & $60 \%$ & 4 & $18 \%$ & 17 & $49 \%$ & 12 & $21 \%$ & 10 & $28 \%$ & 46 & $30 \%$ \\
\hline & Total & & & 5 & $100 \%$ & 22 & $100 \%$ & 35 & $100 \%$ & 56 & $100 \%$ & 36 & $100 \%$ & 154 & $100 \%$ \\
\hline
\end{tabular}

Note: Libya Telecom \& Tech - LTT, Libyan - LY, Almadar Aljadid - AAJ

Likert scale: 1 = Strongly disagree, 2 = Disagree, 3 = Neutral, 4 = Agree, $5=$ Strongly agree 
The survey questionnaire findings with regard to the construct for the influence of trust upon the loyalty of customer with the LTS revealed that most participants approved the proposition that loyalty of customers was influenced by trust in LTS. Overall, therefore, the results have consistency with previous studies that have considered trust to be an essential ingredient for creating and preserving relationships over the long-term between consumers and a company (Morgan \& Hunt, 1994), particularly within the context of the sector of telecommunications. Reichheld and Schefter (2000) observed that it was first of all essential to gain trust in order to gain customer loyalty. As with company and customer CC identification, CSR has a positive impact on trust (Swaen \& Chumpitaz, 2008). The trust of consumers is impacted by there being values that are shared by both the consumer and the company (Morgan \& Hunt, 1994). With regard to initiatives for CSR, and as stated by Hosmer (1994), through injection of responsible and ethical principles into the processes of strategic decision-making of a company, it may enhance trust amongst all of its stakeholders, including the customers. Trust-based relationships are stimulated by a perception that a firm is responsible and ethical with a basis in a belief that all the actions of the exchange partner will have credibility beyond any legal or contractual constraints (Morgan \& Hunt, 1994). The recent work of Pivato et al. (2008) supports such a view with their proposal that trust creation is an immediate consequence of the social performance of a company, or the most proximate or immediate outcome of activities for CSR (with behaviours, financial performance and attitude being less central outcomes for CSR). So, it can be considered that associations with CSR will have a positive impact on the trust of customers.

\subsubsection{The impact of service quality upon customer loyalty within the LTS}

Table 7 below highlights investigation findings with regard to respondent opinion over-evaluation of quality of service and its impact upon the loyalty of customers with regard to the LTS. There was the design of 6 statements in order for the variables to be tested through use of a Likert scale with a range from one representing disagree strongly to five representing agree strongly. The mean scores shown in Table 7 fluctuate between the values of 4.64 and 3.10 showing that, on average, the respondents showed consensus with regard to the influence of service quality upon loyalty that customers have in LTS. For a deeper analysis, cross-tabulation was undertaken independently for all of the respondent groups. It can be seen from the frequencies within Table 7 that, generally, the overall direction of participant group responses was highly consistent to the general view of participants as shown within Table 7 below. So that there can be an identifying of any variations in perspectives of customers of LTS in relation to the evaluation of the quality of service and its impact upon loyalty in the LTS of customers, there was the running of a one-way ANOVA test. The outcomes of the one-way ANOVA test highlighted that no significant statistical differences existed with respect to participants in relation to the impact of the quality of service upon the loyalty in LTS of customers where $\mathrm{p}>0.05, \mathrm{~F}(2,151)=$ between 0.762 and 2.204 .

Table 7. Cross-tabulation for companies and the impact of service quality on customer loyalty within the LTS

\begin{tabular}{|c|c|c|c|c|c|c|c|c|c|c|c|c|c|c|c|}
\hline & \multirow[t]{2}{*}{ Mean } & \multirow{2}{*}{$\begin{array}{l}\text { Std. } \\
\text { Dev }\end{array}$} & \multicolumn{2}{|c|}{$\begin{array}{l}\text { Strongly } \\
\text { disagree }\end{array}$} & \multicolumn{2}{|c|}{ Disagree } & \multicolumn{2}{|c|}{ Neutral } & \multicolumn{2}{|c|}{ Agree } & \multicolumn{2}{|c|}{$\begin{array}{c}\text { Strongly } \\
\text { agree }\end{array}$} & \multicolumn{2}{|c|}{ Total } \\
\hline & & & & $F$ & $\%$ & $F$ & $\%$ & $F$ & $\%$ & $F$ & $\%$ & $F$ & $\%$ & $F$ & $\%$ \\
\hline \multirow{4}{*}{$\begin{array}{l}\text { This mobile } \\
\text { telecom operator } \\
\text { follows up on time } \\
\text { to customer } \\
\text { requests. }\end{array}$} & LTT & \multirow{4}{*}{3.52} & \multirow{4}{*}{0.98} & 0 & $0 \%$ & 9 & $39 \%$ & 19 & $32 \%$ & 15 & $38 \%$ & 6 & $19 \%$ & 49 & $32 \%$ \\
\hline & LY & & & 0 & $0 \%$ & 11 & $48 \%$ & 19 & $32 \%$ & 14 & $36 \%$ & 15 & $47 \%$ & 59 & $38 \%$ \\
\hline & AAJ & & & 0 & $0 \%$ & 3 & $13 \%$ & 22 & $37 \%$ & 10 & $26 \%$ & 11 & $34 \%$ & 46 & $30 \%$ \\
\hline & Total & & & 0 & $100 \%$ & 23 & $100 \%$ & 60 & $100 \%$ & 39 & $100 \%$ & 32 & $100 \%$ & 154 & $100 \%$ \\
\hline \multirow{4}{*}{$\begin{array}{l}\text { The frontline } \\
\text { employees of this } \\
\text { operator are always } \\
\text { willing to help me. }\end{array}$} & LTT & \multirow{4}{*}{4.60} & \multirow{4}{*}{0.76} & 0 & $0 \%$ & 1 & $50 \%$ & 6 & $43 \%$ & 10 & $43 \%$ & 32 & $28 \%$ & 49 & $32 \%$ \\
\hline & LY & & & 1 & $100 \%$ & 0 & $0 \%$ & 3 & $21 \%$ & 9 & $39 \%$ & 46 & $40 \%$ & 59 & $38 \%$ \\
\hline & AAJ & & & 0 & $0 \%$ & 1 & $50 \%$ & 5 & $36 \%$ & 4 & $17 \%$ & 36 & $32 \%$ & 46 & $30 \%$ \\
\hline & Total & & & 1 & $100 \%$ & 2 & $100 \%$ & 14 & $100 \%$ & 23 & $100 \%$ & 114 & $100 \%$ & 154 & $100 \%$ \\
\hline \multirow{4}{*}{$\begin{array}{l}\text { The responses to } \\
\text { consumers' } \\
\text { complaints are } \\
\text { always taken } \\
\text { quickly. }\end{array}$} & LTT & \multirow{4}{*}{4.64} & \multirow{4}{*}{0.69} & 0 & $0 \%$ & 1 & $50 \%$ & 6 & $46 \%$ & 10 & $43 \%$ & 32 & $28 \%$ & 49 & $32 \%$ \\
\hline & LY & & & 0 & $0 \%$ & 0 & $0 \%$ & 3 & $23 \%$ & 9 & $39 \%$ & 47 & $41 \%$ & 59 & $38 \%$ \\
\hline & AAJ & & & 0 & $0 \%$ & 1 & $50 \%$ & 4 & $31 \%$ & 4 & $17 \%$ & 37 & $32 \%$ & 46 & $30 \%$ \\
\hline & Total & & & 0 & $100 \%$ & 2 & $100 \%$ & 13 & $100 \%$ & 23 & $100 \%$ & 116 & $100 \%$ & 154 & $100 \%$ \\
\hline \multirow{4}{*}{$\begin{array}{l}\text { This operator is } \\
\text { consistent in } \\
\text { providing quality } \\
\text { communications } \\
\text { service. }\end{array}$} & LTT & \multirow{4}{*}{3.10} & \multirow{4}{*}{1.39} & 11 & $0 \%$ & 2 & $0 \%$ & 16 & $0 \%$ & 16 & $0 \%$ & 4 & $0 \%$ & 49 & $32 \%$ \\
\hline & LY & & & 13 & $0 \%$ & 12 & $0 \%$ & 11 & $0 \%$ & 13 & $0 \%$ & 10 & $0 \%$ & 59 & $38 \%$ \\
\hline & AAJ & & & 6 & $0 \%$ & 6 & $0 \%$ & 11 & $0 \%$ & 7 & $0 \%$ & 16 & $0 \%$ & 46 & $30 \%$ \\
\hline & Total & & & 30 & $100 \%$ & 20 & $100 \%$ & 38 & $100 \%$ & 36 & $100 \%$ & 30 & $100 \%$ & 154 & $100 \%$ \\
\hline \multirow{4}{*}{$\begin{array}{l}\text { This operator } \\
\text { offers personalized } \\
\text { services to meet } \\
\text { customers' need. }\end{array}$} & LTT & \multirow{4}{*}{3.52} & \multirow{4}{*}{0.98} & 0 & $0 \%$ & 9 & $39 \%$ & 19 & $32 \%$ & 15 & $38 \%$ & 6 & $19 \%$ & 49 & $32 \%$ \\
\hline & LY & & & 0 & $0 \%$ & 11 & $48 \%$ & 19 & $32 \%$ & 14 & $36 \%$ & 15 & $47 \%$ & 59 & $38 \%$ \\
\hline & AAJ & & & 0 & $0 \%$ & 3 & $13 \%$ & 22 & $37 \%$ & 10 & $26 \%$ & 11 & $34 \%$ & 46 & $30 \%$ \\
\hline & Total & & & 0 & $100 \%$ & 23 & $100 \%$ & 60 & $100 \%$ & 39 & $100 \%$ & 32 & $100 \%$ & 154 & $100 \%$ \\
\hline \multirow{4}{*}{$\begin{array}{l}\text { This operator } \\
\text { provides timely } \\
\text { information when } \\
\text { there are new } \\
\text { services. }\end{array}$} & LTT & \multirow{4}{*}{4.10} & \multirow{4}{*}{1.06} & 0 & $0 \%$ & 6 & $38 \%$ & 9 & $30 \%$ & 12 & $40 \%$ & 22 & $28 \%$ & 49 & $32 \%$ \\
\hline & LY & & & 0 & $0 \%$ & 8 & $50 \%$ & 4 & $13 \%$ & 13 & $43 \%$ & 34 & $44 \%$ & 59 & $38 \%$ \\
\hline & AAJ & & & 0 & $0 \%$ & 2 & $13 \%$ & 17 & $57 \%$ & 5 & $17 \%$ & 22 & $28 \%$ & 46 & $30 \%$ \\
\hline & Total & & & 0 & $100 \%$ & 16 & $100 \%$ & 30 & $100 \%$ & 30 & $100 \%$ & 78 & $100 \%$ & 154 & $100 \%$ \\
\hline
\end{tabular}

Note: Libya Telecom \& Tech - LTT, Libyan - LY, Almadar Aljadid - AAJ

Likert scale: 1 = Strongly disagree, 2 = Disagree, $3=$ Neutral, $4=$ Agree, 5 = Strongly agree 
The findings from the survey questionnaire, with regard to the construct for the influence of quality of service upon the loyalty of customers within the LTS, shows that most participants were in agreement that service quality did impact upon the loyalty of customers within the LTS. There is, therefore, consistency of these results overall with the findings of lots of scholars who discovered that the perceptions of consumers with regard to the efforts towards CSR of a company do have a direct bearing upon their assessment of the quality of service provided by a company (Poolthong \& Mandhachitara, 2009). Quality of service is considered to be a key factor in the evaluation of customers and their selection of services, and could even lead to the changing of the provider of service (Keaveney, 1995). Perceptions of quality are a reason for customers to purchase any particular product or service and helps in differentiation of brands and/or products from those offered by competitors (Zeithaml, 1988); perceptions of quality are key to the maintaining of customer relationships over the long-term and plays a significant role in influence on the intention to purchase (Snoj, Pisnik Korda, \& Mumel, 2004; Vlachos, Tsamakos, Vrechopoulos, \& Avramidis, 2009). The example of Body Shop was used by Rummell (1999) to show how the use of ingredients that are natural and the adoption of practices that are environmentally-friendly has led to associations that are positive between its products and the perceptions of consumers. It was found by Sen and Bhattacharya (2001) that consumers have sensitivity with regard to the implications of activities for CSR and the ability to exceed the expectations of a company. For instance, Crespo and Rodríguez del Bosque (2005) discovered that the perception of consumers in relation to behaviour around CSR may have a direct impact on their assessment of service and its quality. Research has encouraged the strategic use of CSR by marketers for their positioning through incorporation of programmes for CSR that can stimulate customers into perceiving that a brand has high quality of services, such as the advertising for a beauty salon of the benefits for the environment and the skin of using skincare products that are organic (Vlachos et al., 2009). So, therefore, expectations for CSR have a positive relationship with the quality of service.

\section{CONCLUSION}

There was a resolve from the start of this study to purposefully investigate how activities for CSR encourage the loyalty of customers. The objective of the research was ascertaining the extent to which customers had awareness of CSR and the influence of that CSR upon the loyalty of customers within the telecom sector in Libya. From the results, it became apparent that CSR practice had been embraced by the telecom sector in Libya. The mission statement of the company of making a 'Positive contribution to our community and environment' are aligned keenly with the policies for CSR, and this shows how the concept is important for the company.

So that the key factors that underpin this research can be understood fully, there has been an analysis of the fundamental CSR concept and discussion of it from a number of theoretical perspectives. Also, there has been a full discussion of customer loyalty and its antecedents. So, all of the factors needed to understand CSR and loyalty of customers were dissected fully. The construction of the web-based questionnaire survey enabled the gathering of primary data on the issue through the use of the case study of the Libyan telecom sector. The basis for the questionnaire were the categories of age, gender, education level, awareness of CSR of customers, and attitude of customers towards the use of CSR in the telecom sector in Libya. The variables employed for measurement of the influence of CSR upon the loyalty of customers were the legal CSR component, the economic CSR component, the ethical CSR component and the philanthropic CSR component. It can be concluded that CSR is seen as an important aspect of business for retaining customers and for winning customers by way of recommendations by word of mouth. So, companies working in services, it is prudent for them to plan and streamline practices for CSR carefully to sit well within their operations so that goodwill can be gained amongst both stakeholders and the community, and for the building of competitive advantage. Such careful practice has become essential since customers now have a greater awareness of the effects of business operations upon the environment. Businesses are able to build up a competitive advantage by using CSR for improving the image of a brand, building up loyalty in customers and improving the market share of the telecom company within the sector.

There are both industry and geographical limitations to the study since it only focuses upon companies operating within the telecom sector in Libya. As a consequence, the study results only account for the context of telecommunications within Libya. Findings can differ depending upon which country and in which sector such a study is undertaken; as such, it is suggested future research is undertaken to conduct the same kind of study within different geographical locations and within various sectors so that the study findings can be validated. As the findings showed, the awareness that consumers have about the activities for CSR for companies is, in general, low. These findings call for more research into the issue. So that the actual awareness of customers in relation to the engagement of companies in CSR can be examined within the example of telecom sector of Libya, a more extensive research project could be undertaken. The study results would have an interest in those companies and to those interested in the telecommunications field, in general. As this research has shown a positive relationship between the loyalty of customers and engagement in CSR, it would also be interesting to have an investigation into the influence of involvement in CSR from the point of view of financial matters. So, given that CSR has an impact on the behaviour of consumers and is growing in prominence on agendas in the corporate world, a stream of notable further research projects could examine the effect of investment in CSR upon actual returns. 


\section{REFERENCES}

1. Aaker, D. A. (1996). Measuring brand equity across products and markets. California Management Review, 38(3), 102-120. https://doi.org/10.2307/41165845

2. Akinpelu, Y. A., Ogunbi, O. J., Olaniran, Y. A., \& Ogunseye, T. O. (2013). Corporate social responsibility activities disclosure by commercial banks in Nigeria. European Journal of Business and Management, 5(7), 173-185.

3. Alcañiz, E. B., Herrera, A. A., Manzano, J. A., \& Pérez, R. C. (2011). Efectos de la responsabilidad social corporativa percibida por el consumidor sobre el valor y la satisfacción con el servicio. European Journal of Management and Business Economics, 20(4), 139-160.

4. Ali, W., Frynas, J. G., \& Mahmood, Z. (2017). Determinants of corporate social responsibility (CSR) disclosure in developed and developing countries: A literature review. Corporate Social Responsibility and Environmental Management, 24(4), 273-294. https://doi.org/10.1002/csr.1410

5. AlMutairi, S. M., \& Yen, D. (2017). International diffusion of digital innovations: Mapping the mobile telephony of the Arab States. The Bottom Line, 30(4), 310-329. https://doi.org/10.1108/BL-08-2017-0020

6. Anderson, E. W., \& Mittal, V. (2000). Strengthening the satisfaction-profit chain. Journal of Service Research, 3(2), 107-120. https://doi.org/10.1177/109467050032001

7. Anderson, R. E., \& Srinivasan, S. S. (2003). E-satisfaction and e-loyalty: A contingency framework. Psychology \& Marketing, 20(2), 123-138. https://doi.org/10.1002/mar.10063

8. Barnea, A., \& Rubin, A. (2010). Corporate social responsibility as a conflict between shareholders. Journal of Business Ethics, 97(1), 71-86. https://doi.org/10.1007/s10551-010-0496-z

9. Barone, M. J., Miyazaki, A. D., \& Taylor, K. A. (2000). The influence of cause-related marketing on consumer choice: Does one good turn deserve another? Journal of the Academy of Marketing Science, 28(2), 248-262. https://doi.org/10.1177/0092070300282006

10. Bediako, B. (2017). The impact of corporate social responsibility on customer loyalty. A case study of StanBed Tours ky. Retrieved from https://pdfs.semanticscholar.org/464a/002fa4b3c398255eac6419899bf00a854e77 .pdf?_ga=2.113350724.2131129253.1577357729-666124969.1576504157

11. Bhattacharya, C. B., \& Sen, S. (2003). Consumer-company identification: A framework for understanding consumers' relationships with companies. Journal of Marketing, 67(2), 76-88. https://doi.org/10.1509/jmkg.67.2.76.18609

12. Boshoff, C., \& Gray, B. (2004). The relationships between service quality, customer satisfaction and buying intentions in the private hospital industry. South African Journal of Business Management, 35(4), 27-37. https://doi.org/10.4102/sajbm.v35i4.666

13. Bowie, N. E., \& Freeman, R. E. (Eds.) (1992). Ethics and agency theory: An introduction. Oxford, UK: Oxford University Press.

14. Brammer, S., \& Millington, A. (2005). Corporate reputation and philanthropy: An empirical analysis. Journal of Business Ethics, 61(1), 29-44. https://doi.org/10.1007/s10551-005-7443-4

15. Brown, T. J., \& Dacin, P. A. (1997). The company and the product: Corporate associations and consumer product responses. Journal of Marketing, 61(1), 68-84. https://doi.org/10.2307/1252190

16. Carroll, A. B. (1979). A three-dimensional conceptual model of corporate performance. The Academy of Management Review, 4(4), 497-505. https://doi.org/10.5465/amr.1979.4498296

17. Chaudhuri, A., \& Holbrook, M. B. (2001). The chain of effects from brand trust and brand affect to brand performance: The role of brand loyalty. Journal of Marketing, 65(2), 81-93. https://doi.org/10.1509/jmkg.65.2.81.18255

18. Cheers, Z. (2011). The corporate social responsibility debate. Retrieved from https://digitalcommons.liberty. edu/honors/219/

19. Chiou, J. S., \& Droge, C. (2006). Service quality, trust, specific asset investment, and expertise: Direct and indirect effects in a satisfaction-loyalty framework. Journal of the Academy of Marketing Science, 34(4), 613627. https://doi.org/10.1177/0092070306286934

20. Chiu, C. F. (2009). Correlation between transnational corporate social responsibility, perceived service quality, trust, and repurchase intentions (Unpublished Master Thesis, Dayeh University, Changhua, Taiwan).

21. Christopher, E., \& Luke, M. (2013). The pivotal role of corporate social responsibility perception on consumer behavior. Journal of Business Management Research, 2, 47-55.

22. Churchill Jr., G. A., \& Surprenant, C. (1982). An investigation into the determinants of customer satisfaction. Journal of Marketing Research, 19(4), 491-504. https://doi.org/10.2307/3151722

23. Clarkson, M. E. (1995). A stakeholder framework for analyzing and evaluating corporate social performance. Academy of Management Review, 20(1), 92-117. https://doi.org/10.2307/258888

24. Crespo, A. H., \& Rodríguez del Bosque, I. (2005). Influence of corporate social responsibility on loyalty and valuation of services. Journal of Business Ethics, 61(4), 369-385. https://doi.org/10.1007/s10551-005-5841-2

25. Crosby, L. A., Evans, K. R., \& Cowles, D. (1990). Relationship quality in services selling: An interpersonal influence perspective. Journal of Marketing, 54(3), 68-81. https://doi.org/10.2307/1251817

26. Danielson, M. G., Heck, J. L., \& Shaffer, D. (2008). Shareholder theory - How opponents and proponents both get it wrong. Journal of Applied Finance (Formerly Financial Practice and Education), 18(2). https://doi.org/10.2139/ ssrn.1309066

27. Dick, A. S., \& Basu, K. (1994). Customer loyalty: Toward an integrated conceptual framework. Journal of the Academy of Marketing Science, 22(2), 99-113. https://doi.org/10.1177/0092070394222001

28. Du, S., Bhattacharya, C. B., \& Sen, S. (2010). Maximizing business returns to corporate social responsibility (CSR): The role of CSR communication. International Journal of Management Reviews, 12(1), 8-19. https://doi.org/10. $1111 / \mathrm{j} .1468-2370.2009 .00276 . x$

29. Dunham, L., Freeman, R. E., \& Liedtka, J. (2006). Enhancing stakeholder practice: A particularized exploration of community. Business Ethics Quarterly, 16(1), 23-42. https://doi.org/10.5840/beq20061611

30. Edvardsson, B., Johnson, M. D., Gustafsson, A., \& Strandvik, T. (2000). The effects of satisfaction and loyalty on profits and growth: Products versus services. Total Quality Management, 11(7), 917-927. https://doi.org/10.1080/09544120050135461

31. Eisenhardt, K. M. (1989). Agency theory: An assessment and review. Academy of Management Review, 14(1), 57 74. https://doi.org/10.2307/258191 
32. Ellen, P. S., Webb, D. J., \& Mohr, L. A. (2006). Building corporate associations: Consumer attributions for corporate socially responsible programs. Journal of the Academy of Marketing Science, 34(2), 147-157. https://doi.org/10.1177/0092070305284976

33. Enahoro, J. A., Akinyomi, O. J., \& Olutoye, E. A. (2013). Corporate social responsibility and financial performance: Evidence from Nigerian manufacturing sector. Retrieved from https://www.semanticscholar.org/paper/Corporatesocial-responsibility-and-financial-from-Enahoro-Akinyomi/c62c7360207f61243c51c2af16119ce5c4114ecf

34. Fama, E. F. (1980). Agency problems and the theory of the firm. Journal of Political Economy, 88(2), 288-307. https://doi.org/10.1086/260866

35. Fasanya, I. O., \& Onakoya, A. B. (2013). Does corporate social responsibility improve financial performance of Nigerian firms? Empirical evidence from triangulation analysis. Acta Universitatis Danubius, 9(3), 22-36.

36. Fein, S., \& Hilton, J. L. (1994). Judging others in the shadow of suspicion. Motivation and Emotion, 18(2), 167198. https://doi.org/10.1007/BF02249398

37. Foreh, M. R., \& Grier, S. (2003). When is honesty the best policy? The effect of stated company intent on consumer skepticism. Journal of Consumer Psychology, 13(3), 349-356. https://doi.org/10.1207/S15327663JCP1303_15

38. Fornell, C., Mithas, S., Morgeson III, F. V., \& Krishnan, M. S. (2006). Customer satisfaction and stock prices: High returns, low risk. Journal of Marketing, 70(1), 3-14. https://doi.org/10.1509/jmkg.70.1.003.qxd

39. Freeman, R. E. (1984). Strategic management: A stakeholder approach. Boston, MA: Pitman.

40. Freeman, R. E. (2010). Strategic management: A stakeholder approach. Cambridge, UK: Cambridge University Press.

41. Freeman, R. E., Wicks, A. C., \& Parmar, B. (2004). Stakeholder theory and "the corporate objective revisited". Organization Science, 15(3), 364-369. https://doi.org/10.1287/orsc.1040.0066

42. Friedman, M. (1962). Capitalism and freedom. Chicago, IL: University of Chicago Press.

43. Friedman, M. (1970, September 13). The social responsibility of business is to increase its profits. The New York Times Magazine. Retrieved from http://umich.edu/ thecore/doc/Friedman.pdf

44. Garriga, E., \& Melé, D. (2004). Corporate social responsibility theories: Mapping the territory. Journal of Business Ethics, 53(1-2), 51-71. https://doi.org/10.1023/B:BUSI.0000039399.90587.34

45. Gefen, D., Straub, D., \& Boudreau, M.-C. (2000). Structural equation modeling and regression: Guidelines for research practice. Communications of the Association for Information Systems, 4, 2-76. https://doi.org/10. 17705/1CAIS.00407

46. Germanova, R. (2008). Corporate social responsibility as corporate governance tool: The practice by the business in Bulgaria (Master thesis). Retrieved from http://www.eiod.org/uploads/Publications/Pdf/Master\%20Thesis\% 20Ralitza\%20Germanova.pdf

47. He, H., \& Li, Y. (2011). CSR and service brand: The mediating effect of brand identification and moderating effect of service quality. Journal of Business Ethics, 100(4), 673-688. https://doi.org/10.1007/s10551-010-0703-y

48. Hill, C. W., \& Jones, T. M. (1992). Stakeholder-agency theory. Journal of Management Studies, 29(2), 131-154. https://doi.org/10.1111/j.1467-6486.1992.tb00657.x

49. Hosmer, L. T. (1994). Strategic planning as if ethics mattered. Strategic Management Journal, 15(S2), 17-34. https://doi.org/10.1002/smj.4250151003

50. Jensen, M. C. (2002). Value maximization, stakeholder theory, and the corporate objective function. Business Ethics Quarterly, 12(2), 235-256. https://doi.org/10.2307/3857812

51. Kang, G. D. (2006). The hierarchical structure of service quality: Integration of technical and functional quality. Managing Service Quality: An International Journal, 16(1), 37-50. https://doi.org/10.1108/09604520610639955

52. Karnani, A. (2010, August 23). The case against corporate social responsibility. Wall Street Journal. Retrieved April 29, 2019, from https://www.wsj.com/articles/SB10001424052748703338004575230112664504890

53. Keaveney, S. M. (1995). Customer switching behavior in service industries: An exploratory study. Journal of Marketing, 59(2), 71-82. https://doi.org/10.2307/1252074

54. Keller, K. L. (1993). Conceptualizing, measuring, and managing customer-based brand equity. Journal of Marketing, 57(1), 1-22. https://doi.org/10.2307/1252054

55. Kennedy, M. S., Ferrell, L. K., \& LeClair, D. T. (2001). Consumers' trust of salesperson and manufacturer: An empirical study. Journal of Business Research, 51(1), 73-86. https://doi.org/10.1016/S0148-2963(99)00039-9

56. Klein, J., \& Dawar, N. (2004). Corporate social responsibility and consumers' attributions and brand evaluations in a product-harm crisis. International Journal of Research in Marketing, 21(3), 203-217. https://doi.org/10.1016/j.ijresmar.2003.12.003

57. Kotler, P., \& Armstrong, G. (2010). Principles of marketing. London, UK: Pearson Education.

58. Kotler, P., \& Lee, N. (2008). Corporate social responsibility: Doing the most good for your company and your cause. Hoboken, NJ: John Wiley \& Sons.

59. Kyoon Yoo, D., \& Ah Park, J. (2007). Perceived service quality: Analyzing relationships among employees, customers, and financial performance. International Journal of Quality \& Reliability Management, 24(9), 908926. https://doi.org/10.1108/02656710710826180

60. Lee, E. M., Park, S. Y., Rapert, M. I., \& Newman, C. L. (2012). Does perceived consumer fit matter in corporate social responsibility issues? Journal of Business Research, 65(11), 1558-1564. https://doi.org/10.1016/j.jbusres.2011.02.040

61. Lee, K. Y., Huang, H. L., \& Hsu, Y. C. (2007). Trust, satisfaction and commitment-on loyalty to international retail service brands. Asia Pacific Management Review, 12(3), 161-169.

62. Lee, M. D. P. (2008). A review of the theories of corporate social responsibility: Its evolutionary path and the road ahead. International Journal of Management Reviews, 10(1), 53-73. https://doi.org/10.1111/j.14682370.2007.00226.x

63. Lemon, K. N., White, T. B., \& Winer, R. S. (2002). Dynamic customer relationship management: Incorporating future considerations into the service retention decision. Journal of Marketing, 66(1), 1-14. https://doi.org/10. 1509/jmkg.66.1.1.18447

64. Lichtenstein, D. R., Drumwright, M. E., \& Braig, B. M. (2004). The effect of corporate social responsibility on customer donations to corporate-supported nonprofits. Journal of Marketing, 68(4), 16-32. https://doi.org/10. 1509/jmkg.68.4.16.42726

65. Lichtenstein, D. R., Ridgway, N. M., \& Netemeyer, R. G. (1993). Price perceptions and consumer shopping behavior: A field study. Journal of Marketing Research, 30(2), 234-245. https://doi.org/10.2307/3172830 
66. Liu, C. T., Guo, Y. M., \& Lee, C. H. (2011). The effects of relationship quality and switching barriers on customer loyalty. International Journal of Information Management, 31(1), 71-79. https://doi.org/10.1016/j.ijinfomgt. 2010.05.008

67. Luo, X., \& Bhattacharya, C. B. (2006). Corporate social responsibility, customer satisfaction, and market value. Journal of Marketing, 70(4), 1-18. https://doi.org/10.1509/jmkg.70.4.001

68. Maignan, I., Ferrell, O. C., \& Ferrell, L. (2005). A stakeholder model for implementing social responsibility in marketing. European Journal of Marketing, 39(9/10), 956-977. https://doi.org/10.1108/03090560510610662

69. Maignan, I., Ferrell, O. C., \& Hult, G. T. M. (1999). Corporate citizenship: Cultural antecedents and business benefits. Journal of the Academy of Marketing Science, 27(4), 455-469. https://doi.org/10.1177/0092070399274005

70. Mandhachitara, R., \& Poolthong, Y. (2011). A model of customer loyalty and corporate social responsibility. Journal of Services Marketing, 25(2), 122-133. https://doi.org/10.1108/08876041111119840

71. Mäntysaari, P. (2008). The law of corporate finance: General principles and EU law. Berlin/Heidelberg, Germany: Springer.

72. Masruki, R., Zakaria, N., \& Ibrahim, N. (2012). Value relevance of accounting numbers: Determinants of corporate social responsibility (CSR) disclosures of Islamic banks in Malaysia. The Journal of Muamalat and Islamic Finance Research, 204(1167), 1-58. https://doi.org/10.12816/0004295

73. Mithas, S., Krishnan, M. S., \& Fornell, C. (2005). Why do customer relationship management applications affect customer satisfaction? Journal of Marketing, 69(4), 201-209. https://doi.org/10.1509/.jmkg.2005.69.4.201

74. Morck, R., Shleifer, A., \& Vishny, R. W. (1988). Management ownership and market valuation: An empirical analysis. Journal of Financial Economics, 20, 293-315. https://doi.org/10.1016/0304-405X(88)90048-7

75. Morgan, R. M., \& Hunt, S. D. (1994). The commitment-trust theory of relationship marketing. Journal of Marketing, 58(3), 20-38. https://doi.org/10.2307/1252308

76. Niekerk, M. v., \& Getz, D. (2019). Perspectives on stakeholder theory. In M. v. Niekerk \& D. Getz (Eds.), Event stakeholders. Oxford, UK: Goodfellow Publishers.

77. Öberseder, M., Schlegelmilch, B. B., \& Murphy, P. E. (2013). CSR practices and consumer perceptions. Journal of Business Research, 66(10), 1839-1851. https://doi.org/10.1016/j.jbusres.2013.02.005

78. Oh, H. J., Hong, K. W., \& Kim, H. C. (2013). The influence of multidimensional aspects of service quality, communication on customer satisfaction and customer behavior-focused on the Airline Service. Korean Business Education Review, 28(3), 273-295.

79. Oliver, R. L. (1999). Whence consumer loyalty? Journal of Marketing, 63(4_suppl1), 33-44. https://doi.org/10.11 $77 / 00222429990634 \mathrm{~s} 105$

80. Orel, F. D., \& Kara, A. (2014). Supermarket self-checkout service quality, customer satisfaction, and loyalty: Empirical evidence from an emerging market. Journal of Retailing and Consumer Services, 21(2), 118-129. https://doi.org/10.1016/j.jretconser.2013.07.002

81. Pavlou, P. A., \& Fygenson, M. (2006). Understanding and predicting electronic commerce adoption: An extension of the theory of planned behavior. MIS Quarterly, 30(1), 115-143. https://doi.org/10.2307/25148720

82. Pérez, A., \& Rodríguez del Bosque, I. (2015a). An integrative framework to understand how CSR affects customer loyalty through identification, emotions and satisfaction. Journal of Business Ethics, 129(3), 571-584. https://doi.org/10.1007/s10551-014-2177-9

83. Pérez, A., \& Rodríguez del Bosque, I. (2015b). Corporate social responsibility and customer loyalty: Exploring the role of identification, satisfaction and type of company. Journal of Services Marketing, 29(1), 15-25. https://doi.org/10.1108/JSM-10-2013-0272

84. Pérez, A., del Mar García de los Salmones, M., \& Rodríguez del Bosque, I. (2013). The effect of corporate associations on consumer behaviour. European Journal of Marketing, 47(1/2), 218-238. https://doi.org/10.11 $08 / 03090561311285529$

85. Phillips, R. (2003). Stakeholder legitimacy. Business Ethics Quarterly, 13(1), 25-41. https://doi.org/10.5840/beq 20031312

86. Pivato, S., Misani, N., \& Tencati, A. (2008). The impact of corporate social responsibility on consumer trust: The case of organic food. Business Ethics: A European Review, 17(1), 3-12. https://doi.org/10.1111/j.14678608.2008.00515.x

87. Pomering, A., \& Dolnicar, S. (2006). Customers' sensitivity to different measures of corporate social responsibility in the Australian banking sector. Retrieved from http://ro.uow.edu.au/cgi/viewcontent.cgi?article=1252\& context=commpapers

88. Poolthong, Y., \& Mandhachitara, R. (2009). Customer expectations of CSR, perceived service quality and brand effect in Thai retail banking. International Journal of Bank Marketing, 27(6), 408-427. https://doi.org/10. $1108 / 02652320910988302$

89. Quinn, D. P., \& Jones, T. M. (1995). An agent morality view of business policy. Academy of Management Review, 20(1), 22-42. https://doi.org/10.2307/258885

90. Reichheld, F. F., \& Schefter, P. (2000). E-loyalty: Your secret weapon on the web. Harvard Business Review, 78(4), 105-113.

91. Ross III, J. K., Patterson, L. T., \& Stutts, M. A. (1992). Consumer perceptions of organizations that use cause-related marketing. Journal of the Academy of Marketing Science, 20(1), 93-97. https://doi.org/10.1007/BF02723480

92. Rouf, D. (2011). The corporate social responsibility disclosure: A study of listed companies in Bangladesh. Business and Economics Research Journal, 2(3), 19-32.

93. Rummell, T. (1999). What's new at the body shop? Global Cosmetic Industry, 165(5), 16-18.

94. Russo, A., \& Perrini, F. (2010). Investigating stakeholder theory and social capital: CSR in large firms and SMEs. Journal of Business Ethics, 91(2), 207-221. https://doi.org/10.1007/s10551-009-0079-z

95. Saleem, S., Kumar, A., \& Shahid, A. (2016). Arguments against corporate social responsibility. Imperial Journal of Interdisciplinary Research, 2(8), 946-950.

96. Schaefer, B. P. (2008). Shareholders and social responsibility. Journal of Business Ethics, 81(2), $297-312$. https://doi.org/10.1007/s10551-007-9495-0

97. Seglin, J. L. (2002). How business can be good (and why being good is good for business). In L. P. Hartman (Ed.), Perspectives in business ethics (2nd ed.) (pp. 260-264). New York, NY: The McGraw-Hill Companies. 
98. Sen, S., \& Bhattacharya, C. B. (2001). Does doing good always lead to doing better? Consumer reactions to corporate social responsibility. Journal of Marketing Research, 38(2), 225-243. https://doi.org/10.1509/jmkr. 38.2.225.18838

99. Sen, S., Bhattacharya, C. B., \& Korschun, D. (2006). The role of corporate social responsibility in strengthening multiple stakeholder relationships: A field experiment. Journal of the Academy of Marketing Science, 34(2), 158166. https://doi.org/10.1177/0092070305284978

100.Shankman, N. A. (1999). Reframing the debate between agency and stakeholder theories of the firm. Journal of Business Ethics, 19(4), 319-334. https://doi.org/10.1023/A:1005880031427

101.Sirdeshmukh, D., Singh, J., \& Sabol, B. (2002). Consumer trust, value, and loyalty in relational exchanges. Journal of Marketing, 66(1), 15-37. https://doi.org/10.1509/jmkg.66.1.15.18449

102.Smith, H. J. (2003). The shareholders vs. stakeholders debate. MIT Sloan Management Review, 44(4), 85-90.

103.Snoj, B., Pisnik Korda, A., \& Mumel, D. (2004). The relationships among perceived quality, perceived risk and perceived product value. Journal of Product \& Brand Management, 13(3), 156-167. https://doi.org/10.1108/10610420410538050

104.Stanaland, A. J., Lwin, M. O., \& Murphy, P. E. (2011). Consumer perceptions of the antecedents and consequences of corporate social responsibility. Journal of Business Ethics, 102(1), 47-55. https://doi.org/10.1007/s10551-0110904-Z

105.Sureshchandar, G. S., Rajendran, C., \& Anantharaman, R. N. (2002). The relationship between service quality and customer satisfaction - A factor specific approach. Journal of Services Marketing, 16(4), 363-379. https://doi.org/10.1108/08876040210433248

106.Swaen, V., \& Chumpitaz, R. C. (2008). Impact of corporate social responsibility on consumer trust. Recherche et Applications en Marketing (English Edition), 23(4), 7-34. https://doi.org/10.1177/205157070802300402

107.Ueltschy, L. C., Laroche, M., Eggert, A., \& Bindl, U. (2007). Service quality and satisfaction: An international comparison of professional services perceptions. Journal of Services Marketing, 21(6), 410-423. https://doi.org/10.1108/08876040710818903

108.UNIDO. (2018). What is CSR? Retrieved March 19, 2019, from https://www.unido.org/our-focus/advancingeconomic-competitiveness/competitive-trade-capacities-and-corporate-responsibility/corporate-socialresponsibility-market-integration/what-csr

109.Verhoef, P. C. (2003). Understanding the effect of customer relationship management efforts on customer retention and customer share development. Journal of Marketing, 67(4), 30-45. https://doi.org/10.1509/jmkg. 67.4.30.18685

110.Vlachos, P. A., Tsamakos, A., Vrechopoulos, A. P., \& Avramidis, P. K. (2009). Corporate social responsibility: Attributions, loyalty, and the mediating role of trust. Journal of the Academy of Marketing Science, 37(2), 170180. https://doi.org/10.1007/s11747-008-0117-x

111.Weiss, T., Kirdahy, M., \& Kneale, K. (2008, October 2016). CEOs on CSR. Forbes. Retrieved April 29, 2019, from https://www.forbes.com/2008/10/16/ceos-csr-critics-lead-corprespons08cx_tw_mk_kk_1016ceos.html\#764861b343ab

112.Wibowo, A. J. (2012). Interaction between corporate social responsibility disclosure and profitability of Indonesia firms. Paper presented at UMT 11th International Annual Symposium on Sustainability Science and Management (pp. 373-380).

113.Zeithaml, V. A. (1988). Consumer perceptions of price, quality, and value: A means-end model and synthesis of evidence. Journal of Marketing, 52(3), 2-22. https://doi.org/10.2307/1251446 